\title{
Hydrological Signatures Based on Event Runoff Coefficients in Rural Catchments of the Iberian Peninsula
}

Encarnación V. Taguas, ${ }^{1}$ Estela Nadal-Romero, ${ }^{2}$ José L. Ayuso, ${ }^{1}$ Javier Casalí, ${ }^{3}$ Patricio Cid, ${ }^{4}$ Jorge Dafonte, ${ }^{5}$ Antonio Canatário-Duarte, ${ }^{6}$ Carla S.S. Ferreira, ${ }^{3}$ Rafael Giménez, ${ }^{3}$ Juan V. Giráldez, ${ }^{1}$ Helena Gómez-Macpherson, ${ }^{8}$ Jose A. Gómez, ${ }^{8}$ J. Carlos González-Hidalgo, ${ }^{2}$ Noemí Lana-Renault, ${ }^{9}$ Ana Lucía, ${ }^{10}$ Luciano Mateos, ${ }^{8}$ Rafael Pérez, ${ }^{1}$ M. Luz Rodríguez-Blanco, ${ }^{11}$ Susanne Schnabel, ${ }^{12}$ M. Pilar Serrano-Muela, ${ }^{13}$ M. Mercedes Taboada-Castro, ${ }^{11}$ M. Teresa Taboada-Castro, ${ }^{11}$ and Ane Zabaleta ${ }^{14}$

\begin{abstract}
:
Hydrological signatures are indices that help to describe the behavior of catchments. These indices can also be used to transfer information from gauged to ungauged catchments. In this study, different approaches were evaluated to determine volumetric runoff coefficients in 18 small/ medium experimental gauged catchments of the Iberian Peninsula and to fit runoff calculations based on precipitation data for gauged and ungauged catchments. Using data derived from 1962 events, rainfall-runoff relationships were characterized and compared in order to evaluate the various hydrological response patterns. Volumetric runoff coefficients and cumulative runoff and precipitation ratios of the events that generated runoff $\left(R_{\text {cum }}\right)$ minimized the root mean square error. A linear fit for the estimation of $R_{\text {cum }}$ in ungauged catchments was based on mean annual precipitation, rates of infiltration, the fraction of forest-land use, and the catchment channel length. Despite high catchment heterogeneity, $R_{\text {cum }}$ resulted in a suitable parameter to evaluate hydrological variability in rural gauged and ungauged catchments. In $50 \%$ of the catchments, the precipitation accounted for less than $50 \%$ of the runoff variation. Annual precipitation, antecedent rainfall, and base flow did not have a high significance in rainfall-runoff relationships, which illustrates the heterogeneity of hydrological responses. Our results highlight the need for signature characterizations of small/medium rural catchments because they are the sources of runoff and sediment discharge into rivers, and it is more economical and efficient to take action to mitigate runoff in rural locations.
\end{abstract}

Key Words: Catchments, Iberian Peninsula, runoff, runoff coefficients

(Soil Sci 2017;182: 00-00)

$\cup$ nderstanding hydrological responses to rainfall events at the catchment scale is essential for developing policies that address water resources conservation and to evaluate the risks linked to a changing environment, changes in land use, urban development, and engineering infrastructure (Chow et al., 1988; Knapp et al., 1991; Mishra and Singh, 2003; Colin et al., 2011; Xing et al., 2015). Hydrological spatiotemporal variability can be characterized by one or more indices, such as statistical parameters of runoff or catchment features and soft data, which define the catchment's hydrological signature (Hrachowitz et al., 2013; Westerberg and

\section{Guest Editor: Emmanouil Varouchakis. \\ ${ }^{1}$ Agronomy and Forestry Engineering School, University of Córdoba, Cordoba, Spain. ${ }^{2}$ Departamento de Geografía, Instituto Universitario de Ciencias Ambientales, Universidad de Zaragoza, Zaragoza, Spain.}

${ }^{3}$ Departamento de Proyectos e Ingeniería Rural, Campus de Arrosadia, Universidad Pública de Navarra, Pamplona, Spain.

${ }^{4}$ Laboratorio Nacional de Genómica para la Biodiversidad, Centro de Investigación y de Estudios Avanzados del Instituto Politécnico Nacional, Irapuato, Mexico.

${ }^{5}$ Department of Agroforestry Engineering, University of Santiago de Compostela, Lugo, Spain.

${ }^{6}$ Escola Superior Agrária-Instituto Politécnico de Castelo Branco, Castelo Branco, Portugal.

${ }^{7}$ Centro de Estudos de Recursos Naturais, Ambiente e Sociedade, Escola Superior Agrária de Coimbra, Coimbra, Portugal.

Instituto de Agricultura Sostenible — CSIC, Córdoba, Spain.

${ }^{9} \mathrm{DCH}$, Physical Geography, University of La Rioja, Logroño, Spain.

${ }^{10}$ Center for Applied Geosciences, Faculty of Science, Eberhard Karls Universität

Tübingen, Tübingen, Germany.

${ }^{11}$ Facultad de Ciencias and Centro de Investigaciones Científicas Avanzadas (CICA), University of A Coruña, Campus de A Coruña, Coruña, Spain.

${ }^{12}$ Geo-Environmental Research Group, Universidad de Extremadura,

Cáceres, Spain.
McMillan, 2013; Westerberg et al., 2016). Signatures are crucial for characterizing the similarity of flow regimes between catchments and for out-scaling information from monitored ones (Alcázar and Palau, 2010; Belmar et al., 2011).

Classic methods in hydrology, such as the rational method (Chow et al., 1988) or the Soil Conservation Service Curve Number (1956), have parameterized basic rainfall-runoff relations through different interpretations of the term "runoff coefficient" $\left(R_{\mathrm{c}}\right)$. In general, $R_{\mathrm{c}}$ is associated with either (i) the ratio of the peak runoff rate to the rainfall intensity during the concentration time in the catchment or

\footnotetext{
${ }^{13}$ Instituto Pirenaico de Ecología - CSIC, Zaragoza, Spain.

${ }^{14}$ Hydro-Environmental Research Group, Science and Technology Faculty, University of the Basque Country, Leioa, Basque Country, Spain.

Address for correspondence: Dr. Encarnación V. Taguas, Agronomy and Forestry Engineering School, University of Campus Rabanales, Leonardo Da Vinci Building, Block 2, 1st Floor, CP 14014, Córdoba, Cordoba, Spain. E-mail: vtaguas@uco.es
}

Financial Disclosures/Conflicts of Interest: This research was supported by the research projects CGL2015-64284-C2-2-R, CGL2015-64284-C2-1-R, CGL2014-52135-C3-3-R, CGL2015-65569-R, CGL2014-56907-R, and AGL2015-65036-C3-1 funded by the MINECO-FEDER (Spanish Ministry of Economy and Competitiveness). E.N.-R. is the beneficiary of a Ramón y Cajal postdoctoral contract (Spanish Ministry of Economy and Competitiveness). For the remaining authors, none were declared.

Received April 29, 2017.

Accepted for publication July 17, 2017.

Copyright (C) 2017 The Author(s). Published by Wolters Kluwer Health, Inc. This is an open-access article distributed under the terms of the Creative Commons Attribution-Non Commercial-No Derivatives License 4.0 (CCBY-NC-ND), where it is permissible to download and share the work provided it is properly cited. The work cannot be changed in any way or used commercially without permission from the journal.

ISSN: 0038-075X

DOI: $10.1097 / S S .0000000000000210$ 
(ii) the ratio of the total runoff to the total rainfall (Dhakal et al., 2012), with the latter being the simplest integrator-indicator of the catchment's hydrological behavior (Colin et al., 2011; Xing et al., 2015). The statistical distributions of $R_{\mathrm{c}}$ and information derived from their percentiles (mean, median, 10th percentile, 90th percentile) are useful in interpreting variability of hydrological responses (Mishra and Singh, 2003). However, these interpretations and their applicability may differ depending on the temporal scale used. Longer timescales, such as monthly, seasonally, or annually, are generally used to design storage infrastructure such as dams (Knapp et al., 1991, Taguas et al., 2015a), whereas shorter timescales (event, subdaily, daily) are usually applied when analyzing floods, sediment load patterns, or geomorphologic/land use variations (Heiser et al., 2015; Duvert et al., 2012; Mateo Lázaro et al., 2016). Estimation of runoff during individual storm events is not common, and so limited data availability (Belmar et al., 2011) creates an important hydrological research gap in our understanding of the main driving factors of $R_{\mathrm{c}}$ (Dhakal et al., 2012; Li et al., 2015; Bennett et al. 2016).

In the Iberian Peninsula (IP), human activities such as agriculture and urbanization can increase runoff coefficients and/or water demands, leading to a rise in the frequency and impact of periodic floods and droughts. Consequently, land-use changes may create higher vulnerability in the management of water resources (Belmar et al., 2011). Numerous studies describe the possible alterations of runoff regimes (e.g., see Batalla et al., 2004; Magdaleno and Fernández, 2011; Belmar et al., 2013; Wang et al., 2017). However, comparative analyses at the event scale and in medium and small catchments are less common, despite the fact that these catchments are usually located in the headwaters of larger catchments. Small and medium catchments are also sites for implementing simple and inexpensive water conservation measures (Lana-Renault et al., 2011, 2014; Nadal-Romero et al., 2016). The aim of this work was to evaluate hydrological signatures of IP rural experimental catchments at the event scale based on rainfall-runoff relationships and volumetric runoff coefficients. Event-scale rainfall-runoff datasets from 18 rural small/medium catchments were studied. The specific objectives were to (i) explore different signatures to determine representative volumetric runoff coefficients at the event scale and (ii) describe hydrological patterns of the catchments through their physical features (topography, soil, and land use), runoff coefficients, and rainfall-runoff relationships.

\section{MATERIALS AND METHODS}

\section{Study Sites and Data Series}

The IP is located in southwestern Europe. The peninsula has a surface area of $583,832 \mathrm{~km}^{2}$, and its geographical limits include mainland Spain and Portugal, Andorra, Gibraltar, and the southernmost edge of France. The highest elevation is the Mulhacén peak, at $3,482 \mathrm{~m}$ above sea level. The IP environmental contrasts are the consequence of Atlantic Ocean westerly winds, the warming influence of easterly winds from the Mediterranean Sea, and the distribution of the main mountain ranges, oriented east-west, which divide the peninsula into three distinct large climatic areas: (i) the north coast; (ii) the midwestern and mideastern regions, reaching down to the south coast; and (iii) the Mediterranean coast (Peña et al., 2016; Fig.1A). The large midwestern region is subdivided into the North and South Plateau with elevations of more than $400 \mathrm{~m}$ above sea level. The topography strongly influences the distribution of climatic variables such as rainfall, temperature, and temperature gradients. Mean annual rainfall ranges from less than $300 \mathrm{~mm}$ in the southeast area (Mediterranean coast) to more than $1,200 \mathrm{~mm}$, and up to 2,000 $\mathrm{mm}$, in the west and north of the peninsula (Fig. 1B). The geology of the IP is the product of a long geological history from Proterozoic times to the present, which produced the complexity of its soils that were generated from igneous, metamorphic, and sedimentary rocks (MAGRAMA, 2016).
Rainfall and runoff events recorded from 1996 to 2014 in 18 small rural experimental catchments $(n=1962)$ were analyzed to evaluate their runoff coefficients and rainfall-runoff relationships (Fig. 1; Tables 1 and 2). Table 1 describes the following attributes of the catchments: drainage area $\left(A_{\mathrm{d}}\right.$; ha); average annual rainfall $(P ; \mathrm{mm})$; average elevation from the digital elevation models of the catchments $(H ; \mathrm{m})$; channel length $(L ; \mathrm{m})$; channel slope $(\mathrm{Sl}$; $\left.\mathrm{m} \cdot \mathrm{m}^{-1}\right)$; soil type; dominant textural class; infiltration rate identified from categories A, B, C, and D of the Curve Number method (Soil Conservation Service, 1956; Inf Vel; $\mathrm{cm} \cdot \mathrm{h}^{-1}$ ); and the surface percentage of land uses, considering agricultural crop fraction (ACF; \%), agricultural orchard fraction (AOF; \%), forest areas fraction $(\mathrm{FF} ; \%)$, rangeland fraction (RF; \%), urban areas fraction (UF; \%), and pastures fraction (PF; \%). Drainage areas of the study catchments ranged from 1.4 to $1,600 \mathrm{ha}$, and the mean annual rainfall varied between 400 and 1,994 mm. Main land uses were agricultural crops, orchards, forest areas, and rangelands located at mean altitudes between 106 and $1,130 \mathrm{~m}$ above sea level.

Study periods and sample sizes in each catchment are presented in Table 2, with a mean of $109 \pm 90$ events. In order to standardize the analysis, the existence of base flow and the criteria considered for the event definition were checked. Only six catchments did not present base flow (Table 2), all of which, with the exception of Barranca de los Pinos (c 1), were located in the midsouthern area. In the other catchments, the base flow separation method of Eckhardt (2005) was applied to quantify direct runoff of each hydrograph. The definition of event was established in each catchment according to size ( $A_{\mathrm{d}}$ and travel time), the hydrological response patterns, and the main objectives of the studies. Identification of events (Table 2) was based on runoff generation and intervals without rainfall pulses of $1 \mathrm{~h}$ (three catchments), $2 \mathrm{~h}$ (three catchments), $6 \mathrm{~h}$ (seven catchments), and $10 \mathrm{~h}$ (two catchments) and empirical evaluations of hyetographs and hydrographs (three catchments).

\section{Exploration of Representative Volumetric Runoff Coefficients at the Event Scale}

\section{Analysis of volumetric runoff coefficients at the event scale obtained from different methods}

The cumulative runoff to rainfall ratios $\left(R_{\mathrm{c}}\right)$ and statistics (mean, median, range, 10th percentile, 90th percentile, SD) for each study catchment event were calculated in order to evaluate their basic attributes (Table 3 ). In addition to the classic definition of $R_{\mathrm{c}}$, runoff coefficients following Hawkins' graphical method $\left(R_{\mathrm{c} \_} \mathrm{H}\right.$; Dhakal et al., 2012), Curve Numbers (CN) obtained from Table 9-1 in USDA-NRCS (1997) for the characteristics of the study catchments (soil, type of vegetation cover, land use/treatment, hydrological condition), the "mean" soil moisture state (antecedent moisture condition II), and the cumulative runoff to rainfall of the events $\left(R_{\text {cum }}\right)$ were considered to explore the most suitable approach for calculating runoff through rainfall values. $R_{\mathrm{c} \_} \mathrm{H}$ is obtained from the asymptotic exponential relationship between runoff coefficients of each event $\left(R_{\mathrm{c}}\right)$ and their corresponding rainfall values. This value represents the runoff coefficient for high rainfall events producing high soil moisture. The example in Fig. 2 shows a typical scatter plot for Aixola (c_3) and an exponential fit with asymptote. In the case of Curve Numbers of the USDA-NRCS methodology, the runoff $(Q ; \mathrm{mm})$ is calculated with Eq. 1 through 4:

$$
\begin{gathered}
S=25.4\left(\frac{1000}{\mathrm{CN}}-10\right) \\
I_{a}=0.2 \cdot S \\
Q=\frac{(P-0.2 S)^{2}}{P+0.8 S}
\end{gathered}
$$




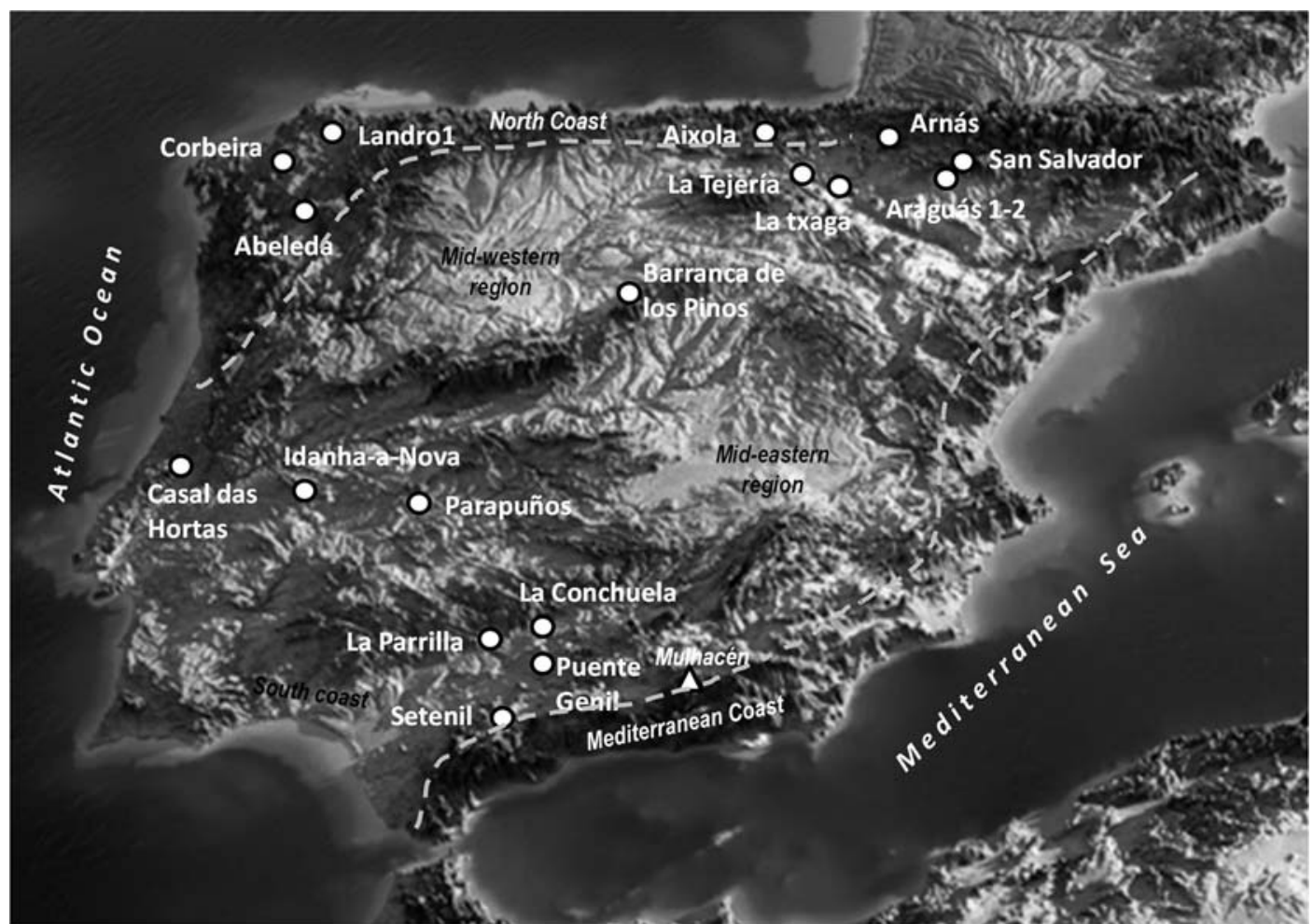

A

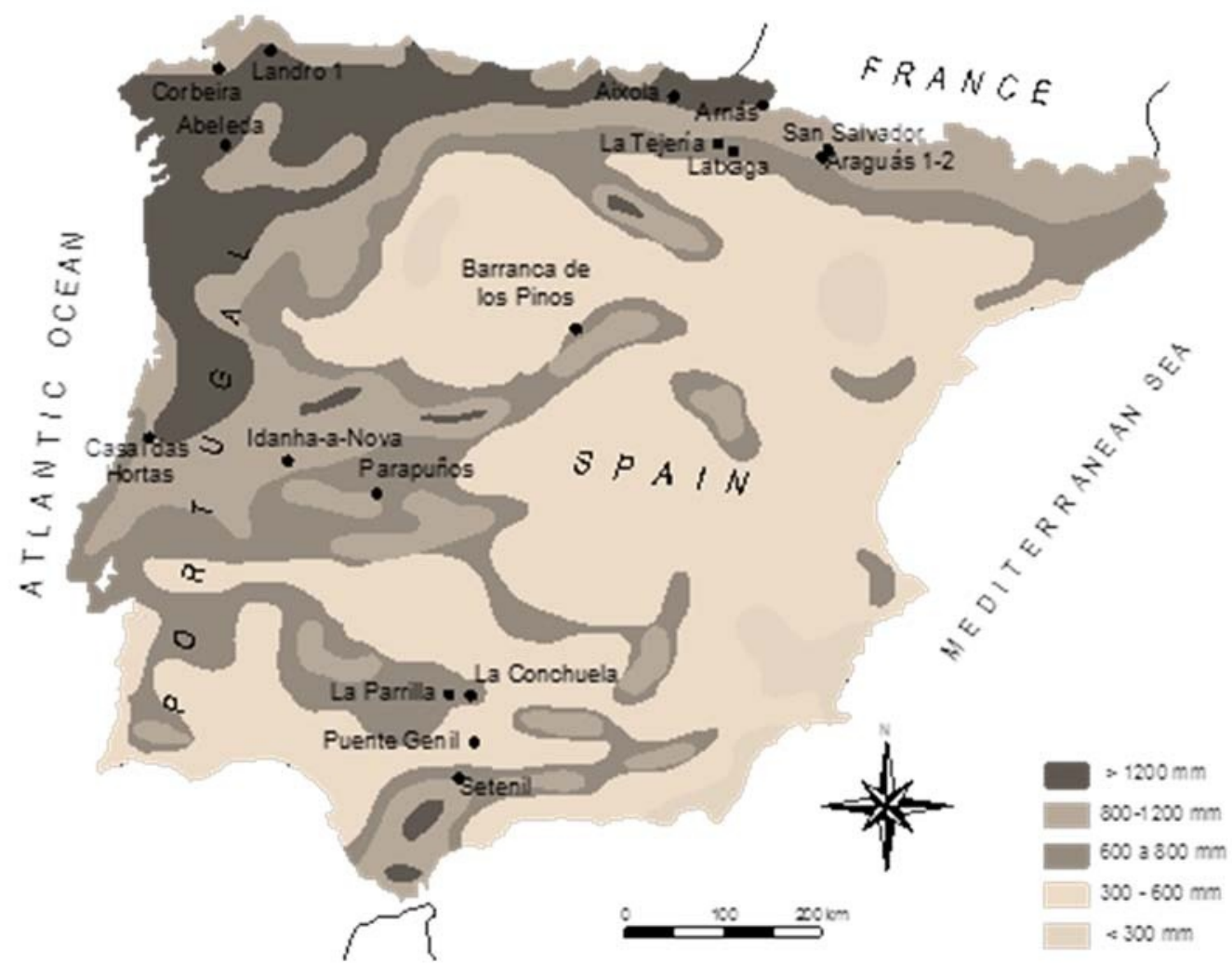

B

FIGURE 1. Location of the study catchments (solid circles with names) in the IP: (A) Topographic shading map (https://es.pinterest.com/) with the different indicated geographical units: north coast, mid-west region, mid-east region, Mediterranean coast, and south coast. The peak of Mulhacén mentioned in the text is also included; (B) spatial rainfall distribution in the IP. A color version of this figure is available in the online version of this article. f(tull color 


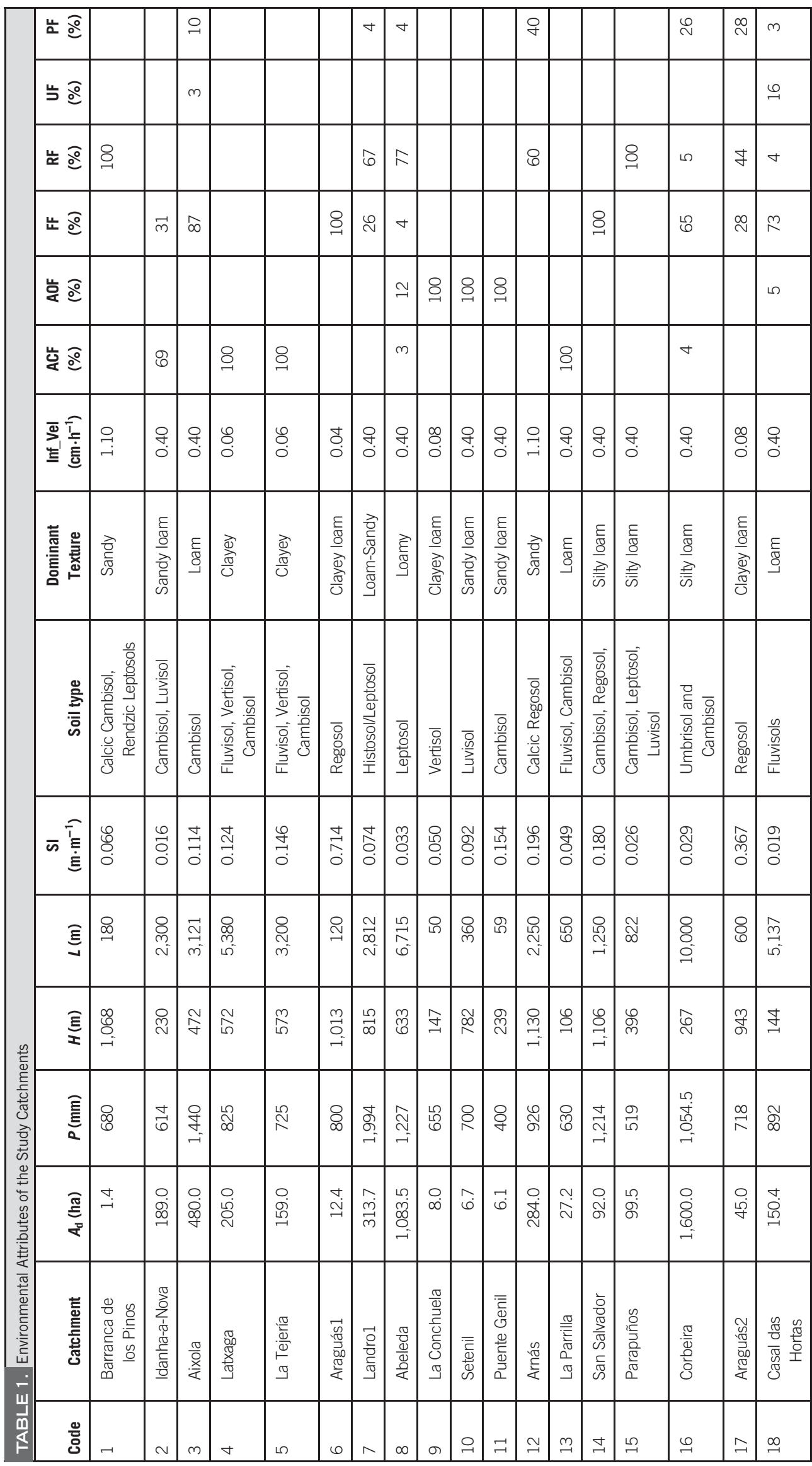




\begin{tabular}{|c|c|c|c|c|c|c|c|c|c|c|c|c|c|c|c|c|c|c|c|}
\hline & . & 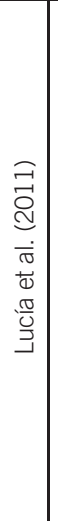 & 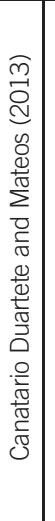 & 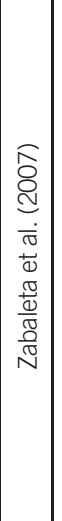 & 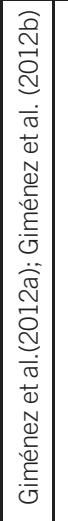 & 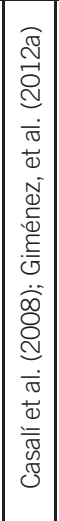 & 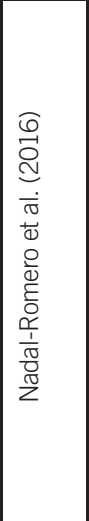 & 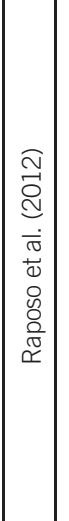 & & 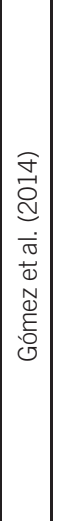 & 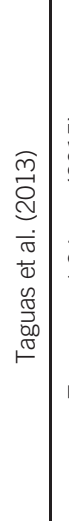 & 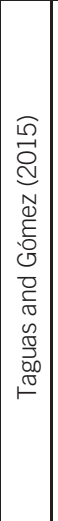 & 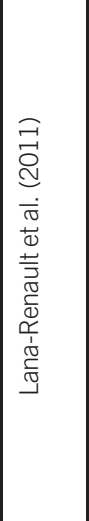 & 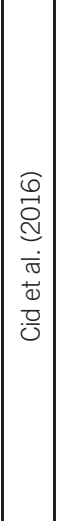 & 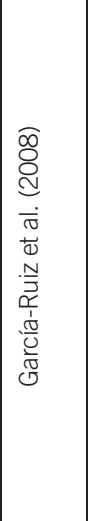 & 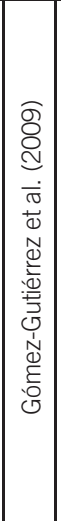 & 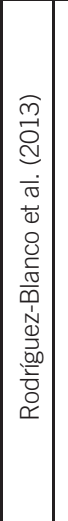 & 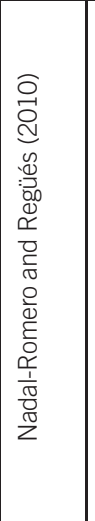 & 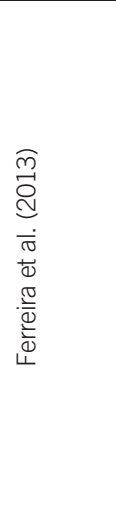 \\
\hline 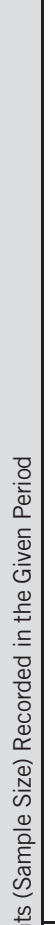 & 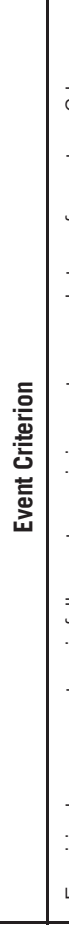 & 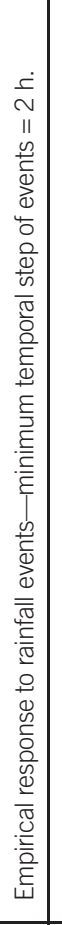 & 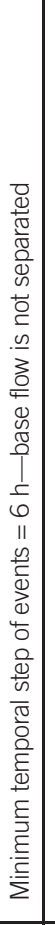 & 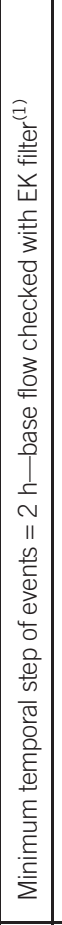 & 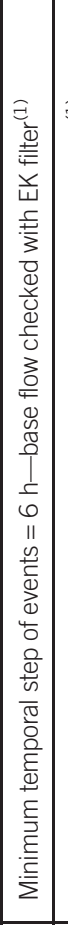 & 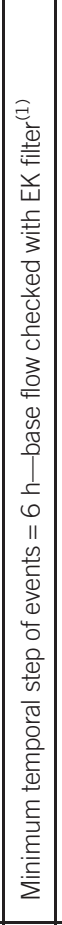 & 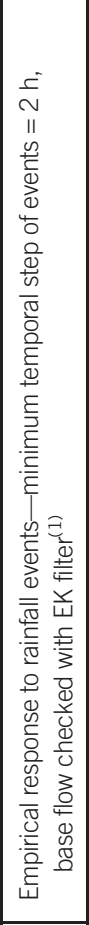 & 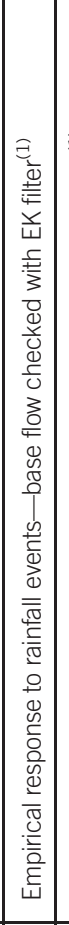 & 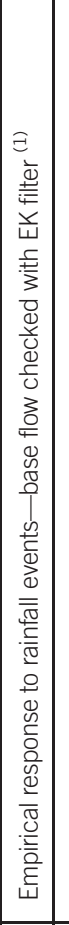 & 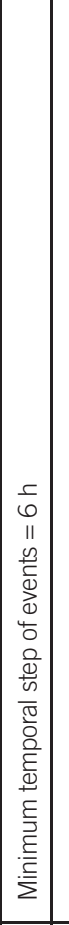 & 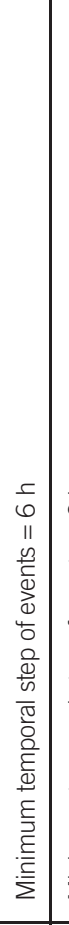 & 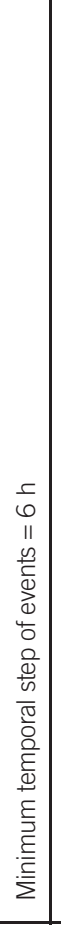 & 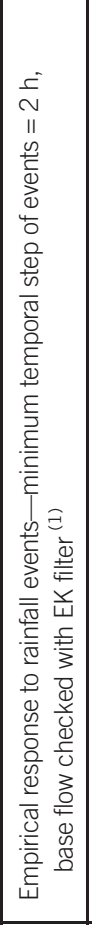 & 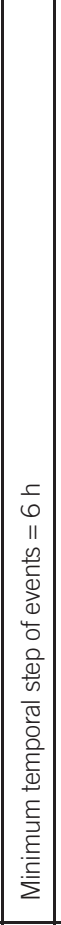 & 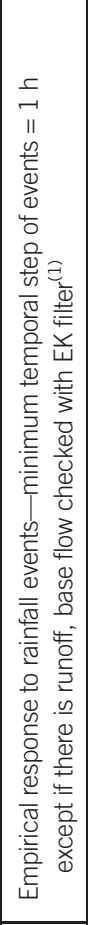 & 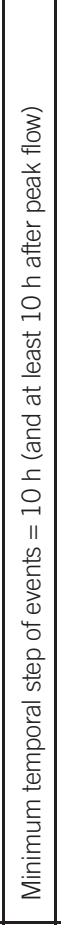 & 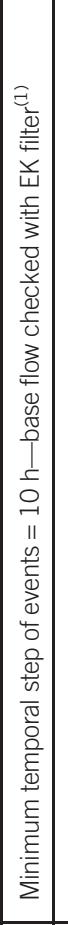 & 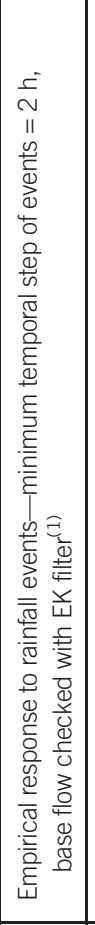 & 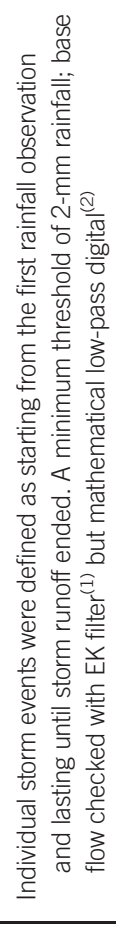 \\
\hline 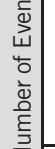 & 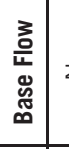 & z & $>$ & $>$ & $>$ & $>$ & $>$ & $>$ & $>$ & $z$ & $z$ & z & $>$ & $z$ & $>$ & $z$ & $>$ & $>$ & $>$ \\
\hline 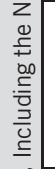 & 离 & 总 & 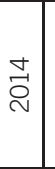 & $\begin{array}{l}\hat{o} \\
\stackrel{1}{ } \\
\hat{\vartheta} \\
\stackrel{\sim}{\sim}\end{array}$ & 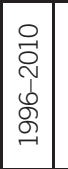 & $\begin{array}{l}0 \\
\stackrel{1}{ } \\
\hat{1} \\
\stackrel{2}{\circ} \\
\stackrel{\sigma}{न}\end{array}$ & 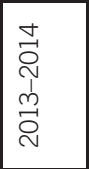 & 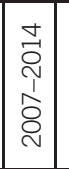 & 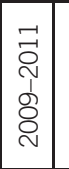 & 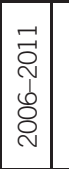 & 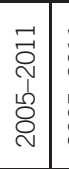 & $\begin{array}{l}\overrightarrow{1} \\
\stackrel{\sim}{1} \\
\hat{d} \\
\dot{\sim}\end{array}$ & 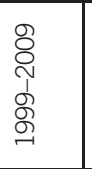 & $\begin{array}{l}m \\
\stackrel{n}{0} \\
\hat{N} \\
\hat{8} \\
\stackrel{\sim}{n}\end{array}$ & 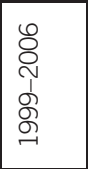 & \begin{tabular}{l}
0 \\
0 \\
0 \\
8 \\
\multirow{2}{*}{$\mid$}
\end{tabular} & 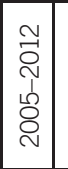 & 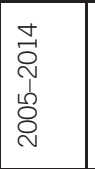 & $\begin{array}{l}m \\
\stackrel{\circ}{\sigma} \\
\stackrel{N}{~} \\
\stackrel{\vec{D}}{\sim}\end{array}$ \\
\hline 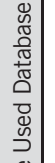 & 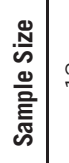 & $m$ & 6 & $\mathbb{N}$ & $\infty$ & 음 & gి & $\stackrel{\varphi}{\oplus}$ & م & 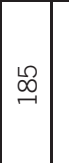 & $\overrightarrow{\underset{I}{*}}$ & R & के & \pm & 只 & $\vec{n}$ & 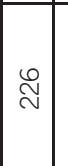 & 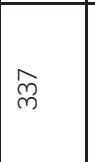 & $\stackrel{\text { I }}{\underset{\mid}{\mid}}$ \\
\hline 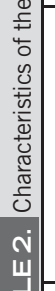 & 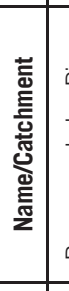 & 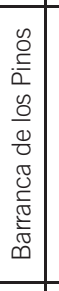 & 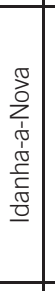 & $\begin{array}{l}\frac{\pi}{2} \\
\frac{x}{2}\end{array}$ & 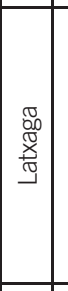 & 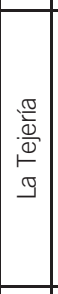 & 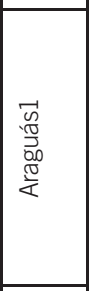 & 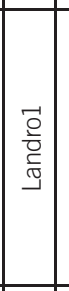 & \begin{tabular}{|l|}
$\frac{\pi}{0}$ \\
$\frac{0}{0}$ \\
$\frac{0}{\alpha}$ \\
$\frac{0}{\alpha}$
\end{tabular} & 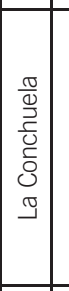 & 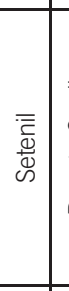 & 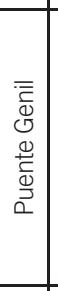 & $\frac{\pi}{5}$ & 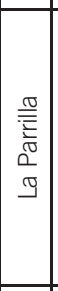 & 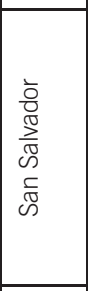 & 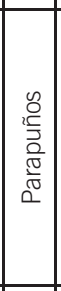 & $\mid$\begin{tabular}{l|}
$\frac{\pi}{\overline{0}}$ \\
$\overline{0}$ \\
$\overline{0}$ \\
0
\end{tabular} & 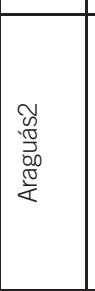 & 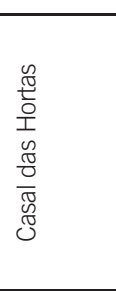 \\
\hline \begin{tabular}{l|l}
$\frac{m}{4}$ \\
$\mathbb{f}$
\end{tabular} & 卷 & $\rightarrow$ & $N$ & $m$ & 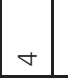 & 兄 & 6 & 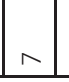 & $\infty$ & a & 으 & $\exists$ & $\cong$ & $\stackrel{m}{\rightarrow}$ & 索 & $\stackrel{2}{\circ}$ & $\stackrel{6}{-1}$ & 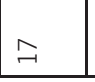 & $\stackrel{\infty}{\rightarrow}$ \\
\hline
\end{tabular}




\begin{tabular}{|c|c|c|c|c|c|c|c|c|c|}
\hline Runoff Coefficients & Catchment & Sample Size & Mean & Median & Min & Max & 10th Percentile & 90th Percentile & SD \\
\hline c_1 & Barranca de los Pinos & 13 & 0.11 & 0.09 & 0.03 & 0.26 & 0.04 & 0.20 & 0.07 \\
\hline c_2* & Idanha-a-Nova & 6 & 0.58 & 0.69 & 0.11 & 0.94 & 0.11 & 0.94 & 0.33 \\
\hline c_3 & Aixola & 222 & 0.04 & 0.02 & 0.00 & 0.40 & 0.01 & 0.10 & 0.05 \\
\hline C_4 & Latxaga & 84 & 0.18 & 0.17 & 0.01 & 0.66 & 0.03 & 0.33 & 0.12 \\
\hline c_5 & La Tejería & 106 & 0.17 & 0.16 & 0.00 & 0.73 & 0.01 & 0.38 & 0.15 \\
\hline c_6 & Araguás1 & 39 & 0.08 & 0.04 & 0.00 & 0.83 & 0.00 & 0.21 & 0.14 \\
\hline c_7 & Landro1 & 16 & 0.42 & 0.43 & 0.11 & 0.70 & 0.20 & 0.64 & 0.18 \\
\hline c_8* & Abeleda & 5 & 0.14 & 0.11 & 0.06 & 0.32 & 0.06 & 0.32 & 0.11 \\
\hline c_9 & La Conchuela & 111 & 0.17 & 0.09 & 0.00 & 0.70 & 0.01 & 0.49 & 0.19 \\
\hline c_10 & Setenil & 121 & 0.18 & 0.15 & 0.00 & 0.64 & 0.02 & 0.39 & 0.15 \\
\hline c_11 & Puente Genil & 79 & 0.09 & 0.02 & 0.00 & 0.77 & 0.00 & 0.29 & 0.15 \\
\hline c_12 & Arnás & 96 & 0.12 & 0.09 & 0.00 & 0.43 & 0.02 & 0.26 & 0.10 \\
\hline c_13 & La Parrilla & 74 & 0.10 & 0.04 & 0.00 & 0.44 & 0.00 & 0.30 & 0.12 \\
\hline c_14 & San Salvador & 54 & 0.17 & 0.07 & 0.00 & 0.65 & 0.00 & 0.45 & 0.19 \\
\hline c_15 & Parapuños & 120 & 0.13 & 0.05 & 0.00 & 0.77 & 0.00 & 0.42 & 0.18 \\
\hline c_16 & Corbeira & 119 & 0.03 & 0.02 & 0.00 & 0.33 & 0.01 & 0.06 & 0.04 \\
\hline c_17 & Araguás2 & 335 & 0.12 & 0.06 & 0.00 & 0.94 & 0.01 & 0.31 & 0.15 \\
\hline c_18 & Casal das Hortas & 145 & 0.07 & 0.05 & 0.00 & 0.99 & 0.01 & 0.14 & 0.10 \\
\hline Mean & & 108 & 0.14 & 0.10 & 0.01 & 0.62 & 0.02 & 0.32 & 0.13 \\
\hline SD & & 79 & 0.09 & 0.10 & 0.03 & 0.20 & 0.05 & 0.15 & 0.05 \\
\hline CV (\%) & & 73 & 64.00 & 103.00 & 269.00 & 32.00 & 208.00 & 46.00 & 35.00 \\
\hline Min & & 13 & 0.03 & 0.02 & 0.00 & 0.26 & 0.00 & 0.06 & 0.04 \\
\hline Max & & 335 & 0.42 & 0.43 & 0.11 & 0.94 & 0.20 & 0.64 & 0.19 \\
\hline
\end{tabular}

*Catchments c_ 2 and c_ 8 were not considered for the global statistics because their sample size was less than 10.

$\mathrm{CV}$, coefficient of variation; Min, minimum; Max, maximum.

$$
\begin{gathered}
\text { If } P>I_{\mathrm{a}} \\
Q=0 \quad \text { If } P>I_{\mathrm{a}}
\end{gathered}
$$

where $S$ is the potential maximum retention ( $\mathrm{mm})$, defined by the dimensionless parameter $\mathrm{CN}$ (Eq. 2); $I_{\mathrm{a}}$ is the initial abstraction $(\mathrm{mm})$ consisting mainly of interception, infiltration, and surface

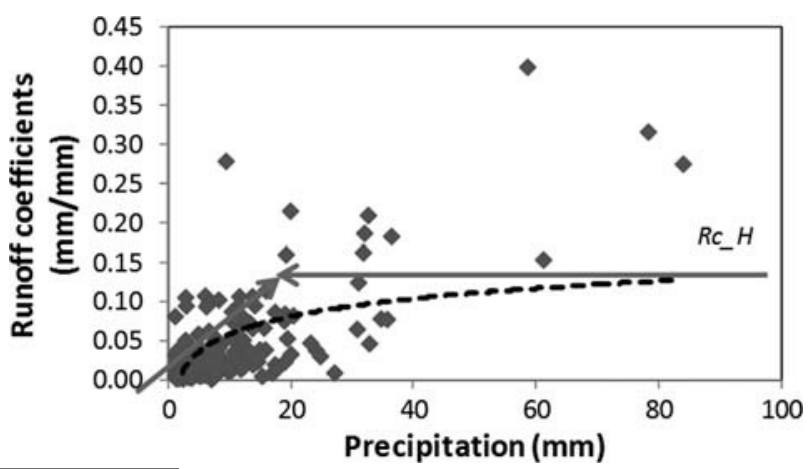

FIGURE 2. Example of the calculation of $R_{c} \_H$ using Aixola (c_3) data. An exponential relationship was fitted to evaluate the runoff coefficient from the observed asymptotic tendency between $R_{\mathrm{c}}$ and precipitation. depression storage during early parts of the storm, and $P$ is the event rainfall $(\mathrm{mm})$.

The performance of different runoff coefficient indices to calculate event runoff through rainfall was checked. The root mean square errors (RMSE) of the observed and estimated runoff when the indices were multiplied by the rainfall of each event were compared, as well as their correlation coefficients $(r)$. These analyses were only applied on the catchments with a data series of $n>10$ events; catchments 2 and 8 were therefore discarded.

\section{Prediction of representative runoff coefficients through multiple linear regression}

After evaluating the most suitable index for gauged catchments, a multiple linear regression (MLR) was employed to relate the main physical features of the catchments (Table 1) with the representative value of runoff coefficient. This was done in order to find a fit that could be used in ungauged catchments. The coefficients for the significant variables and $P$-level of significance were calculated, and the final fit was tested through the $F$ test, the RMSE of the observed and predicted values, and the coefficients of determination $R^{2}$ and adjusted $R^{2}$ (adj. $R^{2}$, which considers the number of degrees of freedom in the analysis). These calculations were carried out using Statistica 8 software (Stat Soft Inc., 2008). 


\section{Hydrological Patterns and Environmental Features in the Study Catchments}

Event rainfall-runoff scatterplots were evaluated for each catchment, as well as the regression coefficients and $R^{2}$ of their corresponding fits. The different types of fits were classified according to observed trends of the calculated regression coefficients (parameters $a$ and $b$ ) and of $R^{2}$ (group of catchments where the rainfall event accounts for $>50 \%$ of the runoff variance, $0.50<R^{2}$, and catchments where the rainfall event accounts for $<50 \%$ of the runoff variance, $0.50>R^{2}$ ). In addition, the effects of the antecedent soil moisture on the runoff response were studied through analysis of the accumulated previous rainfall (APR) on the rainfall-runoff relationships. Consequently, APR was added as a factor to the MLR $\left(Q=a^{*}\right.$ $\left.P+b^{*} \mathrm{APR}+c\right)$ to evaluate previous rainfall contribution to the $R^{2}$ and its significance. With the exception of five catchments (c_4, c 5 c c 6, c 14, and c 17), where the previous rainfall period was $7, \overline{15}$, and/or 21 days, the number of days prior to the event was 10. When different intervals of APR were available, the fit was tested with each of them.

Finally, a principal component analysis (PCA) was used in order to explore the influence of the physical attributes of the catchments on the type of linear fit and the influence of base flow. The aim of this methodology was to isolate the catchments by means of common linearly grouped attributes (Malinowski, 1991). In PCA, the initial variable matrix is changed to noncorrelated synthetic variables called principal components in order to concentrate the analysis on the variables that contribute to the most variance. On the principal axes, the catchment coordinates are the result of contributions of the variance of each studied variable (feature) to the axis. A main axis represents more or less information about a variable according to the value of the principal component, which is equivalent to its degree of correlation. A set of 16 catchments with 12 variables/ attributes $\left\{X_{i}\left(w_{j}\right)\right\}: A_{\mathrm{d}}(\mathrm{ha}), P(\mathrm{~mm}), H(\mathrm{~m}), \mathrm{Sl}\left(\mathrm{m} \cdot \mathrm{m}^{-1}\right)$, Inf Vel $\left(\mathrm{cm} \cdot \mathrm{h}^{-1}\right), \operatorname{ACF}(\%), \operatorname{AOF}(\%), \operatorname{FF}(\%), \operatorname{RF}(\%), \operatorname{UF}(\%), \operatorname{PF}(\%)$, and $R_{\text {cum }}$, were considered. The following steps were taken: (1) the correlation matrix between variables was calculated; (2) the correlations matrix diagonal was set up, and the eigenvalues and eigenvectors for the space change obtained; (3) the projections of individual cases (catchments) on the new axis were calculated; (4) the projection of the variables on the main plane was also calculated to determine their contribution to the formation of each axis; (5) the quality of the representation of the variables and individuals was tested (distances of the projections to plane) to verify the quality of the representation in the principal plane These steps were carried out using Statistica 8 software (Stat Soft Inc., 2008).

\section{RESULTS AND DISCUSSION}

\section{Representative Volumetric Runoff Coefficients at the Event Scale}

\section{Basic statistics and preliminary analysis}

Table 3 presents the mean, median, minimum, maximum, SD, and 10 th and 90th percentiles of $R_{\mathrm{c}}$ in the catchments. Catchments c_2 and $\mathrm{c} 8$ were considered unsuitable for calculating the global statistics because they each had less than 10 events. The mean $R_{\mathrm{c}}$ varied between 0.03 (Corbeira, c_16) and 0.42 (Landro1, c_7) with an average of $0.14 \pm 0.13$. Landro1 (c 7) is the catchment with the highest annual rainfall (nearly $2,000 \mathrm{~mm}$ ). Although it contains other land uses, rangelands dominate c_7, whereas Aixola (c_3) is a forest catchment with steeper slopes and a mean annual rainfall of 1,440 mm (Table 1). Corbeira (c_16) and Casal das Hortas (c_18) also showed values less than 0.14 (0.03 and 0.07 , respectively). Both catchments were characterized by smoother topography, and the fraction of forested area was close to $70 \%$.
However, they are quite distinct in terms of $A_{\mathrm{d}}$ size $(1,600$ and 150 ha, respectively) and soil types (Umbrisol-Cambisol and Regosol-Fluvisols, respectively). Analysis of the medians show only five catchments (c_2 was excluded) with a central value of their distribution larger than 0.10 , which illustrates that under dry conditions most expected runoff coefficients are less than $10 \%$. In 11 of the catchments, the 90th percentiles of $R_{\mathrm{c}}$ were greater than 0.30 , with a maximum of 0.64 in Landro1 (c_7) and a minimum of 0.06 in Corbeira (c_16), which is the largest catchment.

Norbiato et al. (2009), found a similar range of volumetric runoff coefficients (between 0.04 and 0.48 ) and an SD (0.13) close to that of the present study in 14 forest and rangeland catchments in the Italian Alps. However, it was significant how the $R_{\mathrm{c}}$ mean of the catchments was notably greater $(0.28)$ than in this study (0.14). Dhakal et al. (2012) observed wider variation intervals for a group of 90 developed and undeveloped catchments in Texas. In fact, $R_{\mathrm{c}}$ means of these catchments varied between 0.10 and 0.67 , whereas the $R_{\mathrm{c}}$ medians ranged between 0.06 and 0.76 . The influence of developed areas may explain, among other environmental aspects, the notable differences highlighted by the authors to explain $R_{\mathrm{c}}$ variance.

\section{Comparison of indices for gauged catchments}

Table 4 presents a summary of the analysis used to compare RMSE values of runoff obtained when different runoff coefficient indices are considered. The numeric values of the runoff coefficients considered and the RMSE derived from the observed and calculated runoff are shown in Table 4. In addition, the correlation coefficients between observed and calculated runoff and their significance are presented in the columns marked (1) and (2). For $R_{\mathrm{c}} \_\mathrm{H}, R_{\mathrm{c}} \_$med, $R_{\text {cum }}$, and $R_{\mathrm{c}} \_$mean, very close values of $r$ were obtained, and they are presented in column (1), whereas column (2) indicates $r$ values for the analysis with $\mathrm{CN}$.

For all the catchments, the most suitable indices that minimized RMSE were $R_{\mathrm{c}-H}$ and $R_{\text {cum }}$ (Table 4 ), with the exception of Landro1 (c 7), where $\mathrm{CN}$ was the parameter that optimized the error. Evidently, the $\mathrm{CN}$ are not derived from the data series, and these results could be expected (Hjemfelt (1991). Only

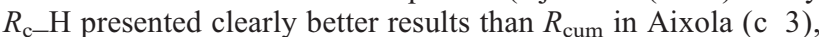
whereas in the other catchments both values were very close, or $R_{\text {cum }}$ provided the best performance. Both indices were strongly correlated ( $r=0.93, P<0.05$; Fig. 3 ); however, $R_{\text {cum }}$ has the clear advantage of being calculated directly from the data series without graphical analysis. In fact, it is worth noting that the $R_{\text {cum }}$ index provided a good performance for a heterogeneous group of catchments, and it is easy to calculate in gauged catchments.

The coefficients of correlation calculated for the best fits were greater than 0.60 in all catchments with the exception of Parapuños

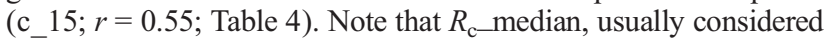
as a reference statistic to select the representative $\mathrm{CN}$ of a site (Soil Conservation Service, 1956), showed a weak correlation ( $r=0.17)$ with the $\mathrm{CN}$ values. $R_{\mathrm{c} \_}$median provided minimum or close to the minimum RMSE for Arnás (c 12) and Casal das Hortas

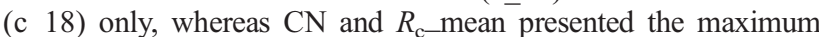
RMSE (Table 4). The range of $\mathrm{CN}$ (Table 4) presented an average of 73 and a variation range between 54 and 84 . The worldwide success of the $\mathrm{CN}$ methodology in calculating storm runoff is that it is well supported by empirical data (Mishra and Singh, 2003). However, after checking its suitability in olive orchard catchments in Spain, Taguas et al. (2015b) suggested reevaluating its application with empirical data. Dhakal et al. (2012) compared the indices of volumetric runoff coefficients obtained from different approaches for catchments in Texas and underlined the lack of correlation among them, which supports the need for studies to check the information in design manuals with badly justified hydrological parameterizations. 


\begin{tabular}{|c|c|c|c|c|c|c|c|c|}
\hline Code/Catchment & Statistic & $R_{\mathrm{c} \_} \mathrm{H}$ & $R_{\mathrm{c} \_}$Med & $R_{\text {cum }}$ & $R_{\mathrm{c} \_ \text {Mean }}$ & $r(1) / P$ & CN & $r(2) / P$ \\
\hline \multirow{2}{*}{$\begin{array}{l}1 \\
\text { Barranca de los Pinos }\end{array}$} & $R_{\mathrm{c}}$ & 0.19 & 0.09 & 0.13 & 0.11 & \multirow{2}{*}{$\begin{array}{l}0.92 \\
0.00\end{array}$} & 68 & \multirow{2}{*}{$\begin{array}{r}-0.35 \\
0.24\end{array}$} \\
\hline & RMSE & 1.44 & 1.79 & 1.46 & 1.67 & & 2.92 & \\
\hline \multirow{2}{*}{$\begin{array}{l}3 \\
\text { Aixola }\end{array}$} & $R_{\mathrm{c}}$ & 0.14 & 0.02 & 0.09 & 0.04 & \multirow{2}{*}{$\begin{array}{l}0.86 \\
0.00\end{array}$} & 74 & \multirow{2}{*}{$\begin{array}{l}0.77 \\
0.00\end{array}$} \\
\hline & RMSE & 1.84 & 2.79 & 2.13 & 2.58 & & 2.46 & \\
\hline \multirow{2}{*}{$\begin{array}{l}4 \\
\text { Latxaga }\end{array}$} & $R_{\mathrm{c}}$ & 0.2 & 0.17 & 0.2 & 0.18 & \multirow{2}{*}{$\begin{array}{l}0.69 \\
0.00\end{array}$} & 84 & \multirow{2}{*}{$\begin{array}{l}0.76 \\
0.00\end{array}$} \\
\hline & RMSE & 6.66 & 6.99 & 6.64 & 6.81 & & 6.76 & \\
\hline \multirow{2}{*}{$\begin{array}{l}5 \\
\text { La Tejería }\end{array}$} & $R_{\mathrm{c}}$ & 0.11 & 0.16 & 0.09 & 0.17 & \multirow{2}{*}{$\begin{array}{l}0.64 \\
0.00\end{array}$} & 84 & \multirow{2}{*}{$\begin{array}{l}0.65 \\
0.00\end{array}$} \\
\hline & RMSE & 2.59 & 2.85 & 2.63 & 3.03 & & 5.68 & \\
\hline \multirow{2}{*}{$\begin{array}{l}6 \\
\text { Araguás1 }\end{array}$} & $R_{\mathrm{c}}$ & 0.12 & 0.04 & 0.1 & 0.08 & \multirow{2}{*}{$\begin{array}{l}0.60 \\
0.00\end{array}$} & 79 & \multirow{2}{*}{$\begin{array}{l}0.53 \\
0.00\end{array}$} \\
\hline & RMSE & 2.7 & 3.11 & 2.68 & 2.75 & & 5.85 & \\
\hline \multirow{2}{*}{$\begin{array}{l}7 \\
\text { Landro1 }\end{array}$} & $R_{\mathrm{c}}$ - Value & 0.66 & 0.43 & 0.49 & 0.42 & \multirow{2}{*}{$\begin{array}{l}0.97 \\
0.00\end{array}$} & 73 & \multirow{2}{*}{$\begin{array}{l}0.97 \\
0.00\end{array}$} \\
\hline & RMSE & 18 & 20.09 & 16.20 & 21.06 & & 15.78 & \\
\hline \multirow{2}{*}{$\begin{array}{l}9 \\
\text { La Conchuela }\end{array}$} & $R_{\mathrm{c}}$ & 0.3 & 0.09 & 0.24 & 0.17 & \multirow{2}{*}{$\begin{array}{l}0.73 \\
0.00\end{array}$} & 82 & \multirow{2}{*}{$\begin{array}{l}0.72 \\
0.00\end{array}$} \\
\hline & RMSE & 7.52 & 9.9 & 7.7 & 8.48 & & 9.04 & \\
\hline \multirow{2}{*}{$\begin{array}{l}10 \\
\text { Setenil }\end{array}$} & $R_{\mathrm{c}}$ & 0.28 & 0.15 & 0.2 & 0.18 & \multirow{2}{*}{$\begin{array}{l}0.76 \\
0.00\end{array}$} & 73 & \multirow{2}{*}{$\begin{array}{l}0.71 \\
0.00\end{array}$} \\
\hline & RMSE & 4.83 & 4.96 & 4.47 & 4.62 & & 6.41 & \\
\hline \multirow{2}{*}{$\begin{array}{l}11 \\
\text { Puente Genil }\end{array}$} & $R_{\mathrm{C}}$ & 0.34 & 0.02 & 0.14 & 0.09 & \multirow{2}{*}{$\begin{array}{l}0.62 \\
0.00\end{array}$} & 57 & \multirow{2}{*}{$\begin{array}{r}-0.47 \\
0.00\end{array}$} \\
\hline & RMSE & 5.76 & 5.87 & 4.8 & 5.15 & & 6.99 & \\
\hline \multirow{2}{*}{$\begin{array}{l}12 \\
\text { Arnás }\end{array}$} & $R_{\mathrm{c}}$ & 0.08 & 0.08 & 0.13 & 0.12 & 0.71 & 54 & -0.53 \\
\hline & RMSE & 3.24 & 3.24 & 2.78 & 2.84 & & 5.58 & 0.00 \\
\hline 13 & $R_{\mathrm{c}}$ & 0.26 & 0.04 & 0.17 & 0.1 & 0.85 & 77 & 0.88 \\
\hline La Parrilla & RMSE & 7.11 & 11.92 & 7.39 & 9.43 & 0.00 & 11.01 & 0.00 \\
\hline 14 & $R_{\mathrm{c}}$ & 0.34 & 0.07 & 0.21 & 0.17 & 0.64 & 73 & 0.67 \\
\hline San Salvador & RMSE & 8.67 & 10.18 & 7.93 & 8.33 & 0.00 & 8.24 & 0.00 \\
\hline 15 & $R_{\mathrm{c}}$ & 0.2 & 0.05 & 0.15 & 0.13 & 0.55 & 72 & 0.45 \\
\hline Parapunos & RMSE & 4.34 & 5.06 & 4.37 & 4.44 & 0.00 & 4.61 & 0.00 \\
\hline 16 & $R_{\mathrm{c}}$ & 0.05 & 0.02 & 0.05 & 0.12 & 0.66 & 72 & 0.63 \\
\hline Corbelra & RMSE & 2.44 & 2.75 & 2.39 & 2.82 & 0.00 & 6.51 & 0.00 \\
\hline 17 & $R_{\mathrm{c}}$ & 0.26 & 0.06 & 0.15 & 0.12 & 0.8 & 79 & 0.72 \\
\hline Araguas2 & RMSE & 2.48 & 3.29 & 2.44 & 2.7 & 0.00 & 3.60 & 0.00 \\
\hline 18 & $R_{\mathrm{c}}$ & 0.05 & 0.05 & 0.06 & 0.07 & 0.61 & 76 & -0.33 \\
\hline Casal das & RMSE & 0.03 & 0.03 & 0.03 & 0.03 & 0.00 & 1.84 & 0.00 \\
\hline
\end{tabular}

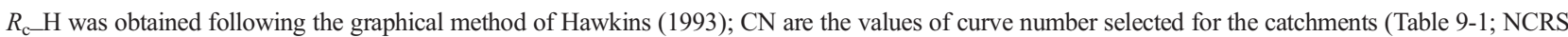

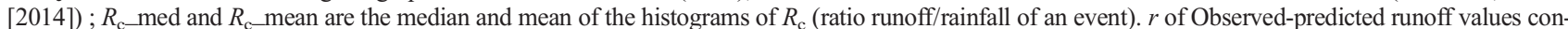

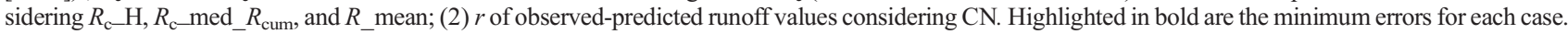

$P$, significance level of the fit; $r$, correlation coefficient between observed and calculated runoff values coefficients.

\section{Prediction of runoff coefficients for ungauged catchments}

Table 5 shows the results of the prediction of $R_{\text {cum }}$ with multilinear regression with the best combination of catchment attributes (Table 1). The model $\left(R_{\text {cum }}=b_{0}+b_{1} * P+b_{2} *\right.$ Inf Vel $+b_{3} *$ $\left.\mathrm{FF}+b_{4} * L\right)$ depended on $P(\mathrm{~mm})$, Inf Vel $(\mathrm{cm})$, FF $(\%)$, and $L$ $(\mathrm{m})$, which illustrates the expected influence of climate, soil type, land cover, and size of catchment. Dependence on similar catchment features were described by Norbiato et al. (2009) for event runoff coefficients observed in 14 catchments in the eastern Italian Alps. Despite catchment heterogeneity, the values of significance for the $F$ test $(0.0006)$ and adj. $R^{2}(0.73)$ indicate that most of the variance was satisfactorily explained by the model. The RMSE was 0.05 . Significance of the coefficients was less than 0.10 , with the exception of the intercept. Figure 4 presents the 


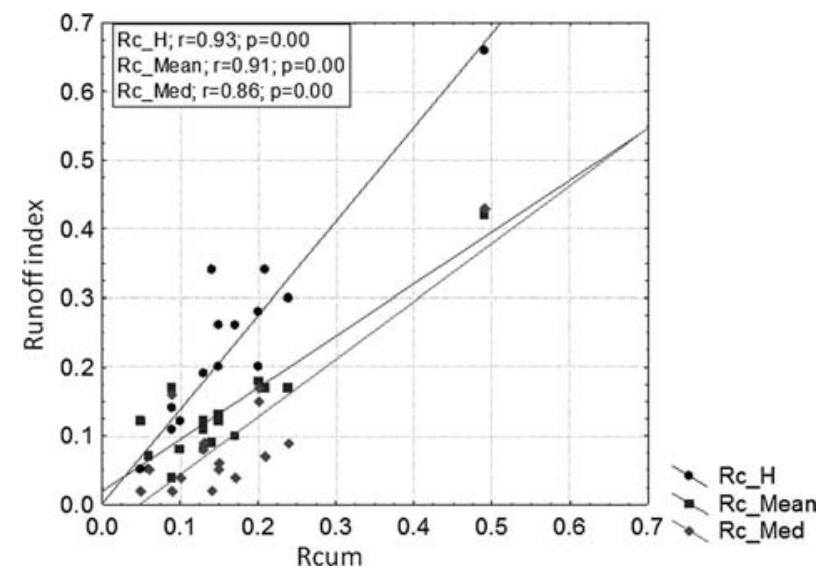

FIGURE 3. Correlation scatterplots of different indices to calculate event runoff in the study catchments: $(\mathrm{A})$ correlations between $R_{\text {cum }}$ and $R_{\mathrm{c} \_} \mathrm{H}, R_{\mathrm{c} \_}$mean, and $R_{\_}$med; $\mathrm{B}$ ) correlations between $\mathrm{CN}$ and $R_{\mathrm{cum}}$, $R_{\mathrm{c} \_} \mathrm{H}, R_{\mathrm{c} \_}$mean, and $R_{-}$med. $R_{\mathrm{c} \_} \mathrm{H}$ was obtained following the graphical method of Hawkins (1993) (Fig. 2); CN are the values of Curve Number selected for the catchments (Table 9-1; NCRS [2014]); $R_{\mathrm{c} \_ \text {med }}$ and $R_{\mathrm{c} \_}$mean are the median and mean statistics of the histograms of $R_{\mathrm{c}}$ (Table 3 ).

scatterplot of the observed and predicted $R_{\text {cum values. It is worth }}$ noting how catchments Aixola (c_3) and Tejería (c_5) presented the maximum deviation, and their $R_{\text {cum }}$ values were notably overestimated. In contrast, the values from San Salvador (c 14) were underestimated (Fig. 4).

The quality of the fittings is comparable with those in D'Ambrosio et al. (2017), who calculated maximum annual flow in terms of significant variables in temporary river systems in Italy. Moreover, similar weaknesses were noted by D'Ambrosio et al. (2017) in relation to the reduced number of catchments and attributes analyzed, which must also be recognized in our study. However, we would like to highlight that (i) abundant literature exists

TABLE 5. Summary of the Best Model Derived From Multiple Linear Regression $\left(R_{\text {cum }}=b 0+b 1^{*} P+b 2^{*}\right.$ Inf_Vel $\left.+b 3^{*} \mathrm{FF}+b 4^{*} L\right)$, Showing the Values of the Coefficients $(b)$ Modifying Each Variable

\begin{tabular}{|l|c|c|c|}
\hline Variables & Coefficients $(\boldsymbol{b})$ & RMSE & $\boldsymbol{P}$ \\
\hline Intercept & 0.049554 & 0.03684 & 0.20569 \\
\hline Mean annual rainfall (mm; $P$ ) & 0.000258 & $4.1 \mathrm{E}-05$ & $6.2 \mathrm{E}-05$ \\
\hline Rate of infiltration (cm/h; Inf_Vel) & -0.085820 & 0.04436 & 0.07914 \\
\hline Forest fraction (\%; FF) & -0.001560 & 0.0004 & 0.00254 \\
\hline Channel length (m; $L)$ & -0.000016 & $5 \mathrm{E}-06$ & 0.01268 \\
\hline Multiple $R: 0.8967, F=11.62866$ \\
\hline$R^{2}: 0.8041, d f=4,11$ & & \\
\hline No. cases: 16, adj. $R^{2}: 0.7328, P=0.000610$ \\
\hline RMSE of the estimate: 0.05320
\end{tabular}

The $F$ value, $d f$ (degrees of freedom), and resulting $P$ (significance) are the statistics of $F$ test to evaluate the relationships between the dependent variable and the set in independent variables.

Adj. $R^{2}$, adjusted coefficient of determination taking into consideration the sample size and the number of predictor variables; multiple $R$, coefficient of correlation among the observed and predicted values of $R_{\text {cum }} ; P$, significance of the fit; $R^{2}$, coefficients of determination; RMSE, root mean square error of the observed and predicted values. showing daily, monthly, and annual stream flows (mainly quantiles and statistical moments) and their regionalization for large gauged and ungauged catchments (Sanborn and Bledsoe, 2006; Alcázar and Palau, 2010; Belmar et al., 2013), but there is a notable gap at the event scale and for small catchments (Merz et al., 2006; Norbiato et al., 2009), and (ii) for a small group of simple features of the catchments, representative runoff coefficients could easily be estimated. In order to improve the statistical performance, more effort should be made to contrast the results by adding new catchments in different climatological areas of the IP, as well as by enlarging the data series.

\section{Hydrological Patterns and Environmental Features}

Table 6 and Figs. 5 and 6 show the results of the classification analysis to evaluate hydrological patterns in the study catchments. Derived from the evaluation of $R^{2}$ on the $P-Q$ fits, in $50 \%$ of the catchments, rainfall accounted for less than $50 \%$ of the runoff variation. Figures 5A of Parapuños (c_15) and 5b of Landro 1 (c_7) show representative rainfall-runoff scatterplots, which present the different trends. The range of variation of $R^{2}$ was between 0.30 (Parapuños, c 15) and 0.94 (Landro1, c 7). The term " $a$ " (Table 6) varied between 0.07 (Casal das Hortas, c_18) and 0.65 (Landro1, c 7), whereas " $b$ " did so between -12.78 (Landro1, c 7) and $-\overline{0} .02$ (Casal das Hortas, c 18). Although $R_{\text {cum }}$ was slightly less than the term " $a$ " (approximately 30\%), both indices were very well correlated with $R_{\text {cum }}(r=0.95, P=0.000)$. For $50 \%$ of the catchments, " $a$ " was between 0.20 and 0.30 , and this is where the best fits were concentrated, with the exception of Landro1 (c 7) and La Conchuela (c 9).

As far as the effects of antecedent precipitation are concerned, APR did not improve the coefficients of determination of the fits when this factor was included in the MLR model (Table 6). Only in Casal das Hortas (c 18) was the increase in adj. $R^{2}$ substantial (from 0.38 to 0.51 ). In addition, APR presented a significance $P>0.05$ in six catchments (38\%; Table 6): Aixola (c 3), Latxaga (c_4), Araguás1 (c_6), Puente Genil (c_11), San Salvador (c_14),

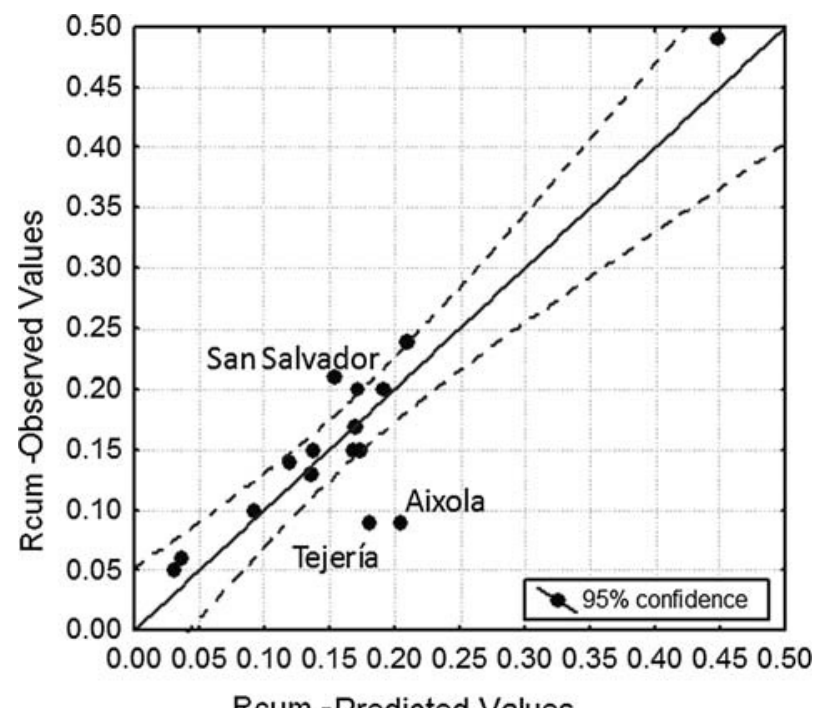

FIGURE 4. Scatterplot of observed and predicted $R_{\text {cum }}$ values derived from the fit $R_{\text {cum }}=b_{0}+b_{1}{ }^{*} P+b_{2}{ }^{*}$ Inf_Vel $+b_{3}{ }^{*} \mathrm{FF}+b_{4}{ }^{*} L$, where $b$ denotes the coefficients of the fit, $P$ is the mean annual precipitation ( $\mathrm{mm})$, Inf_Vel is the rate of infiltration $(\mathrm{cm} / \mathrm{h})$, FF is the percentage of $F F$, and $L$ is the channel length $(m)$. The catchments with maximum deviation have been marked. The dashed lines indicate the limits for $95 \%$ of confidence interval. 


\begin{tabular}{|c|c|c|c|c|c|c|c|}
\hline Name & $Q=a * P+b$ & $a$ & $b$ & $R^{2}$ & APR & Adj. $R^{2}$ & Significance \\
\hline Barranca de los Pinos & c_1 & 0.262 & -1.988 & 0.85 & P10 & 0.88 & $<0.05$ \\
\hline Aixola & c_3 & 0.224 & -1.233 & 0.74 & P10 & 0.74 & $>0.05$ \\
\hline Latxaga & C_4 & 0.329 & -3.501 & 0.48 & P7/P21 & 0.49 & $>0.05$ \\
\hline La Tejería & c_5 & 0.147 & -1.106 & 0.41 & P7/P21 & 0.45 & $<0.05$ \\
\hline Araguás1 & c_6 & 0.106 & -0.154 & 0.36 & P7/P15 & 0.37 & $>0.05$ \\
\hline Landrol & c_7 & 0.649 & -12.780 & 0.94 & P10 & 0.96 & $<0.05$ \\
\hline La Conchuela & c_9 & 0.337 & -2.135 & 0.53 & P10 & 0.54 & $<0.05$ \\
\hline Setenil & c_10 & 0.250 & -1.317 & 0.58 & P10 & 0.60 & $<0.05$ \\
\hline Puente Genil & c_11 & 0.293 & -2.789 & 0.38 & P10 & 0.38 & $>0.05$ \\
\hline Arnás & c_12 & 0.212 & -1.566 & 0.50 & P10 & 0.53 & $<0.05$ \\
\hline La Parrilla & c_13 & 0.292 & -4.562 & 0.72 & P10 & 0.74 & $<0.05$ \\
\hline San Salvador & c_14 & 0.389 & -6.132 & 0.41 & P15 & 0.41 & $>0.05$ \\
\hline Parapuños & c_15 & 0.237 & -1.244 & 0.30 & P10 & 0.31 & $<0.05$ \\
\hline Corbeira & c_16 & 0.088 & -0.887 & 0.43 & P10 & 0.43 & $>0.05$ \\
\hline Araguás2 & c_17 & 0.240 & -0.906 & 0.64 & P7/P15 & 0.65 & $<0.05$ \\
\hline \multirow[t]{6}{*}{ Casal das Hortas } & c_18 & 0.068 & -0.023 & 0.38 & P10 & 0.51 & $<0.05$ \\
\hline & Mean & 0.258 & -2.645 & 0.54 & - & 0.56 & - \\
\hline & SD & 0.139 & 3.146 & 0.19 & - & 0.19 & - \\
\hline & CV (\%) & 53.816 & -118.931 & 34.69 & - & 33.39 & - \\
\hline & Min & 0.068 & -12.780 & 0.30 & - & 0.31 & - \\
\hline & Max & 0.649 & -0.023 & 0.94 & - & 0.96 & - \\
\hline
\end{tabular}

APR is estimated based on accumulated rainfall in the previous 7 (P7), 10 (P10), 15 (P15), or 21 (P21) days. For the all the fits with the simple linear regression model, $P$ was significant at $P<0.05$.

$a$ and $b$, the slopes and the intercepts of the fits, respectively; $\operatorname{Adj}_{-} R^{2}$, variance explained by the MLR considering APR; CV, coefficient of variation; Min, minimum; Max, maximum; $P$, rainfall of the event; $Q$,runoff of the event; $R^{2}$, coefficient of determination.

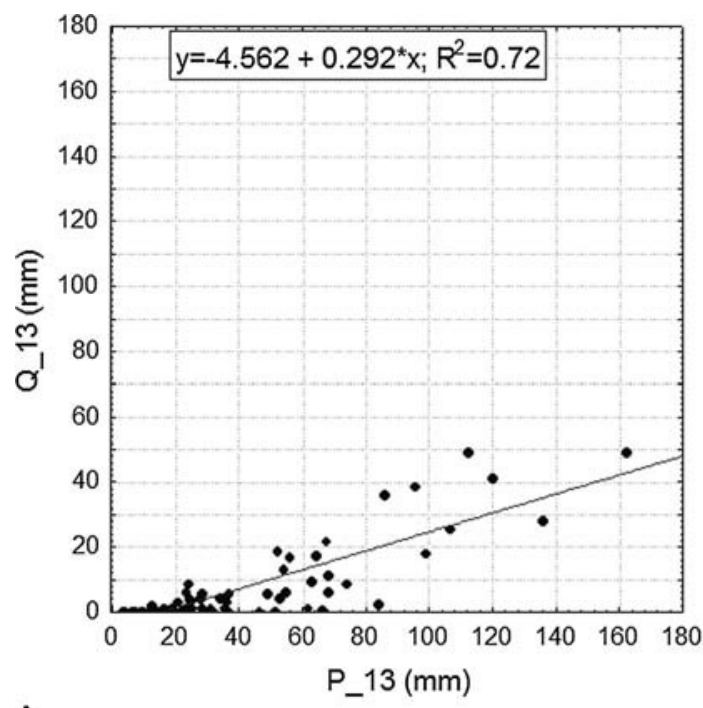

A (B) fits with $R^{2}<0.50$ ( $P=$ precipitation; $Q=$ runoff; the number 11 denotes the code for catchment 11 for Puente Genil, and 13 for La Parrilla).

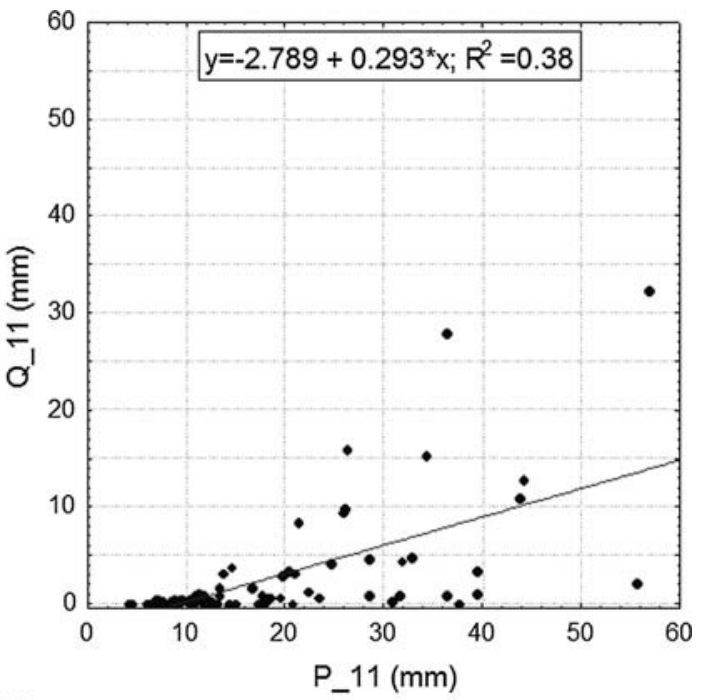

B 


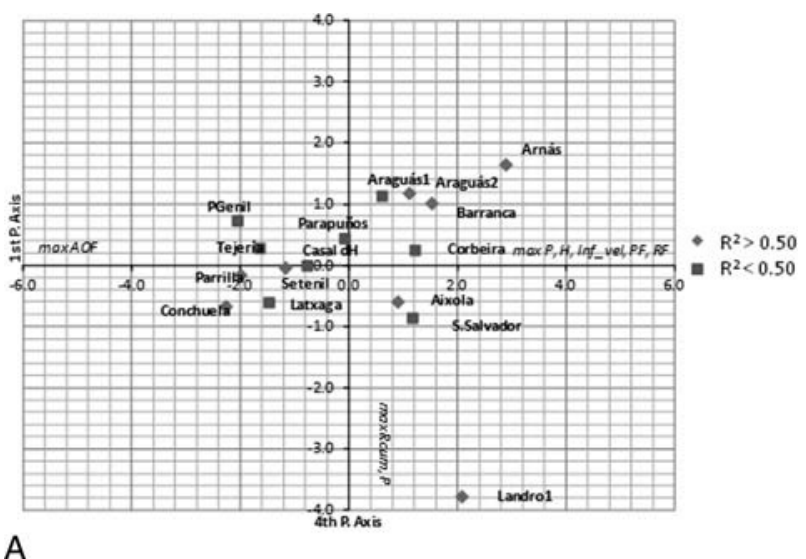

A

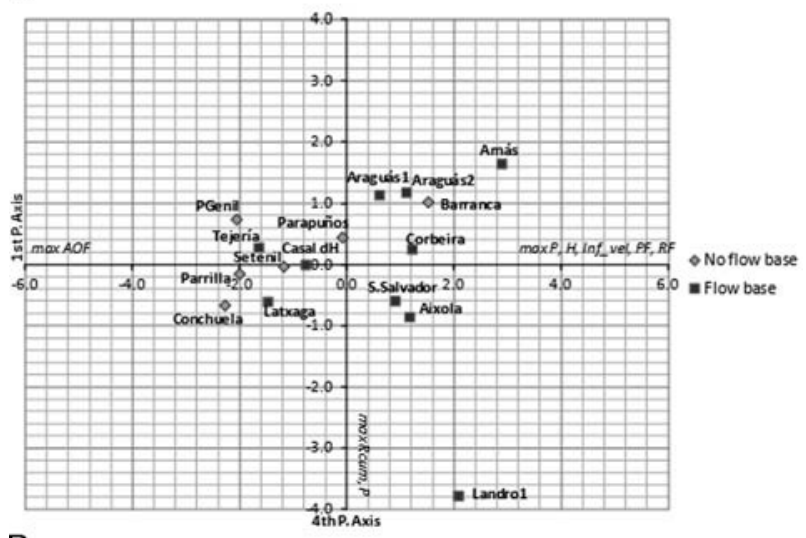

B

FIGURE 6. Representation of the catchments on the plane formed by the first and fourth principal axes: (A) catchments with an $R_{2}>0.50$ in the rainfall-runoff fit (type $\mathrm{A}$ ) and $R_{2}<0.50$ (type $\mathrm{B}$ ) have been marked; (B) catchments with flow base and without flow base have been marked. Max indicates the location of the maximum values for that particular attribute; $P$, average annual rainfall; $H$, average elevation from the digital elevation models of the catchments; $L$, channel length; SI, channel slope; Inf_Vel, infiltration rate identified from categories

A, B, C, and D of the CN method (Soil Conservation Service, 1956).

and Corbeira (c_16). With the exception of Corbeira (c_16), the channel mean slopes of those catchments were larger than $7 \%$, which may indicate steeper slopes and shallower soils and a reduced influence of these variables on runoff generation. It is worth noting that the patterns of runoff generation must be controlled by local physical factors (different from APR) whose spatial variability determines the response in the outlet. Schnabel and GómezGutiérrez (2013) mentioned the importance of soil moisture in the valley bottoms as a key factor to understand the hydrological behavior of Parapuños (c_15). The different response patterns of the catchments such as Araguas1 (c 6) and Araguas2 (c 17) also illustrate the need for specific analysis of the catchments to describe their hydrological behaviour.

Table 7 and Fig. 6 summarize the result of the PCA. The eigenvalues and the percentage of explained variance for each principal axis were as follows: for axis $1,2.70$ and $22.48 \%$; for axis $2,2.25$ and $18.73 \%$; for axis $3,1.82$ and $15.16 \%$; for axis $4,1.57$ and $13.04 \%$; for axis 5, 1.31 and $10.89 \%$; and for axis $6,1.15$ and $9.59 \%$, whereas for the rest of the axes the explained variance was less than $5 \%$. The fourth main axis was correlated with $R_{\text {cum }}$ (projection on PA4 $=-0.80)$ and $P(\mathrm{PA} 4=-0.75)$, and the variance explained by PA 4 was not much lower than the variance explained by the second main axis. If the plane formed by the principal axes 1 and 4 is considered, the cumulative variance adds up to $36 \%$. $P$,
$H$, Inf Vel, AOF, RF, and PF were acceptably represented on the first axis (projection on PA1 $>0.55$; Table 7 ), whereas $P$ and $R_{\text {cum }}$ were on the fourth axis. This is shown in Fig. 6, where the influence of the sign of the projection on the distribution of the catchments (cases) on the principal plane is also indicated. In Fig. 6A, the great heterogeneity of the eight catchments with acceptable linear rainfallrunoff fits can be observed $\left(R^{2}>0.50\right)$. For example, five catchments (Araguás2, Barranca, Arnás, Landro1, and Aixola; c_17, c_1, c_12, c_7, c_3, respectively) were characterized by their land use other than agriculture, the highest value of the annual rainfall and mean altitude, and the high infiltration velocities associated with sandy and loamy textures. On the other hand, despite their agricultural land use and lower values of annual rainfall and altitude, La Parrilla, Setenil, and Conchuela also showed a strong sensitivity to the event rainfall $\left(R^{2}>0.50\right.$, Fig. $6 \mathrm{~A}$; Table 1$)$. The other group of catchments was characterized by four agriculture and pasture land uses (Parapuños, Puente Genil, La Tejería, Latxaga; c_15, c_11, c_5, c_4, respectively), and another four were forest/rangeland catchments with a low variability (with the exception of Landro1, c_7) in terms of annual rainfall range and $R_{\text {cum }}$.

Figure 6B illustrates the lack of correlation between $R_{\text {cum }}$ and the presence of base flow in the catchments. In other words, a higher $R_{\text {cum }}$ (which can be found in the third and the fourth quadrants) did not mean a greater frequency of catchments with base flow. Finally, the influence of $A_{\mathrm{d}}$ was not significant to explain the variance, and it made a negligible contribution toward the formation of axes (Table 7). The event criteria shown in Table 2 did not explain any tendency of the catchments derived from Fig. 6. Finally, another point to underline, which was not included in PCA but can be described if the distribution of catchments is considered, is the low effect of geographical proximity in determining similar hydrological features. This fact can be particularly evident in Araguás1, Araguás2, and San Salvador (Figs. 1 and 6), and it might illustrate the complex hydrological response of the catchments. These findings contrast with analyses carried out in other more humid areas or in the IP. For instance, Mathias et al. (2016) described the nonlinearity of rainfall-runoff in catchments in the United Kingdom associated with more arid catchments in terms of base flow, low rainfall, and evaporative demand. Belmar et al. (2011), referring to the analysis of 390 sections of the Segura River Basin in Spain, described four hydrological categories (large rivers, perennial stable streams, perennial seasonal streams, and intermittent and ephemeral streams) with a high spatial correlation in the response pattern of monthly and annual flow.

Although APR must have influenced the runoff generation, it has a low contribution to explain the runoff at the event and catchment scales. On the other hand, neither the annual rainfall nor the presence of base flow had a clear influence on rainfall-runoff relationships, probably as a result of very different environmental and experimental conditions in the aforementioned cases. Apparently, higher infiltration rates and less forested area may involve less memory or closer initial soil moisture conditions and therefore more constant (linear) response patterns to rainfall. There is a persistent demand for studies that use hydrological indices/signatures to establish criteria to group hydrological regimes in order to identify, among other factors, ecological aspects and the behavior of rivers (BaezaSanz and Garcia de Jalon, 2005; Poff et al., 2010; D'Ambrosio et al., 2017). Despite the heterogeneity of the catchments, rainfallrunoff patterns at the event scale have allowed us to group the catchments into a small number of different response types. Management of small rural catchments is essential because their contribution to rivers in terms of sediment (and water quality) may lead to serious risk of floods, as well as damage to ecological systems. Thus, the characterization of flow patterns of small rural catchments (or signatures) in terms of magnitude and susceptibility of response can provide guidelines for planning and 


\begin{tabular}{|c|c|c|c|c|c|c|c|c|c|c|c|c|}
\hline & PA 1 & PA 2 & PA 3 & PA 4 & PA 5 & PA 6 & PA 7 & PA 8 & PA 9 & PA10 & PA11 & PA.12 \\
\hline$A_{d}$ & 0.33 & -0.47 & 0.53 & -0.09 & -0.30 & -0.45 & 0.16 & 0.15 & -0.06 & -0.17 & -0.05 & 0.00 \\
\hline$P$ & 0.58 & -0.25 & 0.00 & -0.75 & -0.03 & -0.02 & -0.14 & -0.01 & 0.03 & -0.02 & 0.15 & 0.00 \\
\hline $\boldsymbol{H}$ & 0.70 & 0.25 & -0.54 & 0.14 & -0.04 & 0.09 & -0.23 & 0.11 & -0.25 & -0.04 & -0.02 & 0.00 \\
\hline Inf_Vel & 0.55 & 0.44 & 0.45 & 0.23 & 0.20 & 0.15 & -0.30 & 0.27 & 0.18 & -0.04 & -0.03 & 0.00 \\
\hline ACF & -0.52 & -0.02 & 0.02 & -0.06 & -0.76 & 0.32 & -0.21 & 0.02 & 0.02 & -0.04 & 0.00 & 0.00 \\
\hline AOF & -0.55 & 0.31 & -0.07 & 0.00 & 0.49 & -0.57 & -0.15 & 0.02 & -0.03 & -0.06 & 0.04 & 0.00 \\
\hline $\mathrm{FF}$ & 0.37 & -0.82 & -0.24 & -0.10 & 0.25 & 0.06 & 0.05 & 0.20 & 0.04 & 0.12 & -0.06 & 0.00 \\
\hline RF & 0.55 & 0.64 & 0.18 & 0.07 & 0.04 & 0.28 & 0.40 & -0.08 & -0.02 & -0.03 & 0.03 & 0.00 \\
\hline UF & -0.10 & -0.49 & 0.37 & -0.02 & 0.49 & 0.50 & -0.14 & -0.29 & -0.06 & -0.12 & -0.03 & 0.00 \\
\hline PF & 0.62 & -0.08 & 0.26 & 0.35 & -0.23 & -0.39 & -0.18 & -0.41 & 0.02 & 0.10 & -0.01 & 0.00 \\
\hline $\mathrm{SI}$ & 0.22 & -0.26 & -0.82 & 0.36 & -0.04 & -0.04 & 0.06 & -0.12 & 0.17 & -0.16 & 0.02 & 0.00 \\
\hline$R_{\text {cum }}$ & 0.12 & 0.47 & -0.25 & -0.80 & 0.01 & -0.09 & -0.02 & -0.17 & 0.06 & -0.03 & -0.13 & 0.00 \\
\hline
\end{tabular}

Variables in bold are those with principal components $>0.55$ for the principal axes 1 and 4 (see also Fig. 6).

H, average height; Inf_Vel, infiltration velocity identified from categories A, B, C, and D of the CN method (SCS, 1956); P, average annual rainfall; PF, pasture fraction; Sl, channel slope.

implementation of measures to deal with source areas of runoff and sediment, which are eventually discharged into large rivers.

\section{CONCLUSIONS}

In a context of the lack of experimental measurement-based runoff coefficients of small rural catchments in the IP, our results illustrate an empirical method to determine the representative volumetric runoff coefficient for gauged and ungauged catchments. The event rainfall accounted for more than $50 \%$ of the event runoff variance in $50 \%$ of the catchments. The catchments were highly heterogeneous in terms of land use and location in the IP, and neither annual rainfall nor base flow presence contributed significantly to explaining the rainfall-runoff patterns. The previous rainfall had a variable and irrelevant influence on the runoff generation. A greater effort needs to be made to describe and analyze small/medium rural catchments because taking action at this scale can be more economical and efficient than planning measures that are focused solely on the riparian areas of large rivers.

\section{REFERENCES}

Alcázar J., and A. Palau. 2010. Establishing environmental flow regimes in a Mediterranean watershed based on a regional classification. J. Hydrol. 388:41-51

Baeza-Sanz D., and D. Garcia de Jalon. 2005. Characterisation of stream flow regimes in central Spain, based on relevant hydrobiological parameters. J. Hydrol. 310:266-279.

Batalla R. J., C. M. Gómez, and G. M. Kondolf. 2004. Reservoir-induced hydrological changes in the Ebro River basin (NE Spain). J. Hydrol. 290:117-136.

Bennett J. C., D. E. Robertson, P. G. D. Ward, H. A. Prasantha Hapuarachchi, and Q. J. Wang. 2016. Calibrating hourly rainfall-runoff models with daily forcings for streamflow forecasting applications in meso-scale catchments. Environ. Model. Software. 76:20-36.

Belmar O., D. Bruno, F. Martínez-Capel, J. Barquín, and J. Velasco. 2013. Effects of flow regime alteration on fluvial habitats and riparian quality in a semiarid Mediterranean basin. Ecol. Indic. 30:52-64.

Belmar O., J. Velasco, and F. Martinez-Capel. 2011. hydrological classification of natural flow regimes to support environmental flow assessments in intensively regulated Mediterranean Rivers, Segura River Basin (Spain). Environ. Manage. 47:992-1004.
Canatário Duarte A., and L. Mateos. 2013. Contaminação difusa numa pequena bacia hidrográfica com uso agrícola, e impacte na qualidade dos fluxos de retorno. In: VIII Congresso sobre Gestão e Planeamento da Água, Lisboa 5-7 Dec. del Agua, Fundación Nueva Cultura.

Casalí J., R. Gastesi, J. Álvarez-Mozos, L. M. De Santisteban, J. Del Valle de Lersundi, R. Giménez, A. Larrañaga, M. Goñi, U. Agirre, M. A. Campo, J. J. López, and M. Donézar. 2008. Runoff, erosion, and water quality of agricultural watersheds in central Navarre (Spain). Agric. Water Manage. 95:1111-1128.

Cid P., H. Gómez-Macpherson, H. Boulal, and L. Mateos. 2016. Catchment scale hydrology of an irrigated cropping system under soil conservation practices. Hydrol. Proc. 30:4593-4608.

Chow V. T., D. R. Maidment, and L. W. Mays. 1988. Applied Hydrology. McGraw Hill, New York.

Colin F., S. Guillaum, and B. Tisseyre. 2011. Small catchment agricultural management using decision variables defined at catchment scale and a fuzzy rule-based system: A Mediterranean vineyard case study. Water Resour Manage. 25:2649-2668.

D'Ambrosio E., A. M. De Girolamo, E. Barca, P. Ielpo, and M. C. Rulli. 2017. Characterising the hydrological regime of ungauged temporary river system: A case study. Environ. Sci. Pollut. Res. 24:13950-13966.

Dhakal N., X. Fang, P. E. T. G. Cleveland, P. E. D. B. Thompson, P. E. W. H. Asquith, and L. J. Marzen. 2012. Estimation of volumetric runoff coefficients for Texas watersheds using land-use and rainfall-runoff data. ASCE J. Irrig. Drain. Eng. 138:43-54.

Duvert C., G. Nord, N. Gratiot, O. Navratil, E. Nadal-Romero, N. Mathys, J. Némery, D. Regüés, J. M. García-Ruiz, F. Gallart, and M. Esteves. 2012. Towards prediction of suspended sediment yield from peak discharge in small erodible mountainous catchments $(0.45-22 \mathrm{~km} 2)$ of France, Mexico and Spain. J. Hydrol. 454-455:42-55.

Eckhardt K. 2005. How to construct recursive digital filters for baseflow separation. Hydrol. Proc. 19:507-515.

Ferreira C. S. S., T. S. Steenhuis, R. P. D. Walsh, D. Soares, A. J. D. Ferreira, and C. O. A. Coelho. 2013. Land-use change impacts on hydrological soil properties and implications for overland-flow in a periurban Mediterranean catchment. In: EGU General Assembly 2013. Geophysical Research Abstract 15, EGU2013-972, Vienna, Austria.

García-Ruiz J. M., D. Regüés, B. Alvera, N. Lana-Renault, P. Serrano-Muela, E. Nadal-Romero, A. Navas, J. Latron, C. Martí-Bono, and J. Arnáez. 2008. Flood generation and sediment transport in experimental catchments affected by land use changes in the central Pyrenees. J. Hydrol. 356(1-2):245-260.

Giménez R., J. Casalí, and J. Díez. 2012a. Evaluación de la producción de sedimentos y calidad de las aguas en cuencas agrarias de Navarra. Cuadernos Investig. Geogr. 38(1):7-25. 
Giménez R., J. Casalí, I. Grande, J. Díez, M. A. Campo, J. Álvarez-Mozos, and M. Goñi. 2012b. Factors controlling sediment export in a small agricultural watershed in Navarre (Spain). Agric. Water Manage. 110:1-8.

Gómez J. A., T. Vanwalleghem, A. De Hoces, and E. V. Taguas. 2014. Hydrological and erosive response of a small catchment under olive cultivation in a vertic soil during a five-year period: Implications for sustainability. Agric. Ecosyst. Environ. 188:229-244.

Gómez-Gutiérrez A., S. Schnabel, and J. J. Sanjosé Blasco. 2009. Variación temporal de la erosión por cárcavas en los fondos de valle bajo explotación de dehesa. Cuadernos Investig. Geogr. 35(2):289-304.

Hawkins R. H. 1993. Asymptotic determination of runon Curve Number from data. J. Irrig. Drain Eng. 119(2):334-345.

Heiser M., C. Scheidl, J. Eisl, B. Spangl, and J. Hübl. 2015. Process type identification in torrential catchments in the eastern Alps. Geomorphol. 232 (2015):239-247

Hjemfelt A. T. 1991. An investigation of the Curve Number procedure. ASCE J. Hydr. Eng. 117(6):725-737.

Hrachowitz M., H. H. G. Savenije, G. Blöschl, J. J. McDonnell, M. Sivapalan J. W. Pomeroy, B. Arheimer, T. Blume, M. P. Clark, U. Ehret, F. Fenicia, J. E. Freer, A. Gelfan, H. V. Gupta, D. A. Hughes, R. W. Hut, A Montanari, S. Pande, D. Tetzlaff, P. A. Troch, S. Uhlenbrook, T. Wagener, H. C. Winsemius, R. A. Woods, E. Zehe, and C. Cudennec. 2013. A decade of predictions in ungauged basins (PUB): A review. Hydrol. Sci. J. 58(6):1198-1255.

Knapp H. V., A. Durgunoglu, and T. W. Ortel. 1991. A review of rainfallrunoff modeling for stormwater management. U.S. Geologic SurveyIllinois, Champaign, IL.

Lana-Renault N., J. Latron, D. Karssenberg, P. Serrano, D. Regüés, and M. F. P. Bierkens. 2011. Differences in streamflow in relation to changes in land cover: A comparative study in two sub-Mediterranean mountain catchments. J. Hydrol. 411:366-378.

Lana-Renault N., E. Nadal-Romero, M. P. Serrano-Muela, B. Alvera, P. Sánchez-Navarrete, Y. Sanjuan, and J. M. García-Ruiz. 2014. Comparative analysis of the response of various land covers to an exceptional rainfall event in the central Spanish Pyrenees, Earth Surf. Proc. Landf. 39:581-592.

Li Y., X. Li, and G. Li. 2015. Runoff coefficient characteristics and its dominant influence factors of the riparian Myricaria squamosa Desv. shrubs over Qinghai Lake basin, NE Qinghai-Tibet Plateau. Arab J. Geosci. 8:6655-6666.

Lucía A., J. B. Laronne, and J. F. Martín-Duque. 2011. Geodynamics processes on Sandy slope gullies in central Spain field observations, methods and measurements in a singular system. Geodin. Acta. 24(2):61-79.

Lyne V. D., and M. Hollick. 1979. Stochastic time-variable rainfall runoff modelling. Hydrology and Water Resources Symposium, Institution of Engineers, Australia, Perth, Australia, pp. 89-92.

Magdaleno F., and J. A. Fernández. 2011. Hydromorphological alteration of a large Mediterranean river: Relative role of high and low flows on the evolution of riparian forests and channel morphology. River Res. Appl. 27(3):374-387.

Malinowski E. R. 1991. Factor Analysis in Chemistry. 2nd ed. John Wiley, New York.

MAGRAMA - Spanish Ministry of Agriculture and Fishing. Food and Environment. 2016. Atlas climático digital de la Península Ibérica. Available at: http://www.mapama.gob.es/es/ceneam/recursos/pag-web/conservacion/ atlas.aspx. Accessed July 2016.

Mathias S. A., N. McIntyre, and R. H. Oughton. 2016. A study of nonlinearity in rainfall-runoff response using $120 \mathrm{UK}$ catchments. J. Hydrol. 540:423-436.

Mateo Lázaro J., J. Sánchez Navarro, A. García Gil, and V. Edo Romero. 2016. Flood frequency analysis (FFA) in Spanish catchments. J. Hydrol 538:598-608.

Merz R., G. Bloschl, and J. Parajka. 2006. Spatio-temporal variability of event runoff coefficients. J. Hydrol. 331:591-604.

Mishra S. K., and V. Singh. 2003. Soil Conservation Service Curve Number (SCS-CN) methodology. Springer, Dordrecht, Netherlands.

Nadal-Romero E., E. Cammeraat, M. P. Serrano Muela, N. Lana-Renault, and D. Regüés. 2016. Hydrological response of an afforested catchment in a
Mediterranean humid mountain area: A comparative study with a natural forest. Hydrol. Proc. 30(15):2717-2733.

Nadal-Romero E., and D. Regüés. 2010. Geomorphological dynamics of subhumid mountain badland areas-Weathering, hydrological and suspended sediment transport processes: A case study in the Araguás catchment (Central Pyrenees) and implications for altered hydroclimatic regimes. Prog. Phys. Geogr. 34(2):123-150.

Norbiato D., M. Borga, R. Merz, G. Blöschl, and A. Carton. 2009. Controls on event runoff coefficients in the eastern Italian Alps. J. Hydrol. 375: $312-325$.

Peña D.-A., R. M. Trigo, N. Cortesid, and J. C. González-Hidalgo. 2016. The influence of weather types on the monthly average maximum and minimum temperatures in the Iberian Peninsula. Atmos. Res. 178-179: $217-230$.

Poff N. L., B. Richter, A. H. Arthington, S. E. Bunn, R. J. Naiman, E. Kendy, M. Acreman, C. Apse, B. P. Bledsoe, M. Freeman, J. Henriksen, R. B. Jacobson, J. Kennen, D. M. Merritt, J. O’Keeffe, J. D. Olden, K. Rogers, R. E. Tharme, and A. Warner. 2010. The Ecological Limits of Hydrologic Alteration (ELOHA): A new framework for developing regional environmental flow standards. Freshwater Biol. 55:147-170.

Raposo J. R., J. Molinero, and J. Dafonte. 2012. Parameterization and quantification of recharge in crystalline fractured bedrocks in Galicia-Costa (NW Spain). Hydrol. Earth Syst. Sci. 16:1667-1683.

Soil Conservation Service. 1956. Hydrology-National Engineering Handbook, Supplement A, Section 4, Chapter 10. NCRS-USDA, Washington, DC.

Rodríguez-Blanco M. L., M. M. Taboada-Castro, and M. T. Taboada-Castro. 2013. Phosphorus transport into a stream draining from a mixed land use catchment in Galicia (NW Spain): Significance of runoff events. J. Hydrol. 481:12-21

Schnabel A., and A. Gómez-Gutiérrez. 2013. The role of interannual rainfall variability on runoff generation in a small dry sub-humid watershed with disperse tree cover. Cuadernos Investig. Geogr 2013. 39(2):259-285.

Stat Soft Inc. 2008. Statistica 8. Available at: http://www.statsoft.com/. (accessed January 1, 2017).

Sanborn S. C., and B. Bledsoe. 2006. Predicting streamflow regime metrics for ungauged streams in Colorado, Washington, and Oregon. J. Hydrol. 325:241-261

Taguas E. V., J. L. Ayuso, R. Pérez, J. V. Giráldez, and J. A. Gómez. 2013. Intra and inter-annual variability of runoff and sediment yield of an olive micro-catchment with soil protection by natural ground cover in Southern Spain. Geoderma. 206:49-62.

Taguas E. V., and J. A. Gómez. 2015. Vulnerability of olive orchards under the current CAP (Common Agricultural Policy) regulations on soil erosion: A study case in Southern Spain. Land Use Pol. 42:683-694.

Taguas E. V., J. A. Gómez, P. Denisi, and L. Mateos. 2015a. Modelling the rainfall-runoff relationships in a large olive orchard catchment in southern Spain. Water Resour. Manag. 29(7):2361-2375.

Taguas E. V., Y. Yuan, F. Licciardello, and J. A. Gómez. 2015b. Curve Numbers for Olive Orchard catchments: Case study in southern Spain. ASCE J. Irrig. Drain. Eng. 141(11):05015003.

USDA-NRCS Natural Resources Conservation Service. 1997. Part $630 \mathrm{Hy}-$ drology. National Engineering Handbook. US Department of Agriculture, Washington, D.C

Wang X., T. Yang, M. Wortmann, P. Shi, F. Hattermann, A. Lobanova, and V. Aich. 2017. Analysis of multi-dimensional hydrological alterations under climate change for four major river basins in different climate zones. Clim. Change. 141:483-498.

Westerberg I. K., T. Wagener, G. Coxon, H. K. McMillan, A. Castellarin, A. Montanari, and J. Freer. 2016. Uncertainty in hydrological signatures for gauged and ungauged catchments. Water Resour. Res. 52 (3): $1847-1865$

Xing Z., D. Yan, C. Zhang, G. Wang, and D. Zhang. 2015. Spatial characterization and bivariate frequency analysis of precipitation and runoff in the Upper Huai River Basin, China. Water Resour. Manage. 29:3291-3304

Zabaleta A., M. Martínez, J. A. Uriarte, and I. Antigüedad. 2007. Factors controlling suspended sediment yield during runoff events in small headwater catchments of the Basque Country. Catena. 71(1):179-190. 